\title{
Which Factors have an Impact on the Retention of Cemented Crowns on Implant Abutments? A Literature Review
}

\author{
Elisabeth Prause ${ }^{1, *}$, Martin Rosentritt ${ }^{2}$, Florian Beuer ${ }^{1}$, and Jeremias Hey ${ }^{1}$ \\ ${ }^{1}$ Department of Prosthodontics, Geriatric Dentistry and Craniomandibular Disorders, University Charité Berlin, Berlin, Germany \\ ${ }^{2}$ Department of Prosthetic Dentistry, UKR University Hospital Regensburg, Regensburg, Germany
}

*Corresponding author: Elisabeth Prause, Department of Prosthodontics, Geriatric Dentistry and Craniomandibular Disorders, University Charité Berlin, Berlin, Germany, Tel: +49 (0) 30450662 557; E-mail: elisabeth.prause@charite.de

Received: 21 Jul, 2021 | Accepted: 20 Aug, 2021 | Published: 27 Aug, 2021

Citation: Prause E, Rosentritt M, Beuer F, Hey J (2021) Which Factors have an Impact on the Retention of Cemented Crowns on Implant Abutments? A Literature Review. Int J Dent Oral Health 7(5): dx.doi.org/10.16966/2378-7090.378

Copyright: (C) 2021 Prause E, et al. This is an open-access article distributed under the terms of the Creative Commons Attribution License, which permits unrestricted use, distribution, and reproduction in any medium, provided the original author and source are credited.

\begin{abstract}
Background: The review presents the scientific state of the art in the field of cementation of crowns on implants. Because semipermanent cements have been specially developed for the cementation of crowns on implants, the question arises whether this cement group offers an advantage compared to other available and widely used cements in everyday clinical practice. Various factors play a role on the retentive strength of superstructures on implants and should therefore be taken into account in this review.

Materials and methods: A thorough search of the literature, mainly PubMed as well as a manual search, was conducted between 2005 and 2020 to screen relevant articles for data regarding retention forces of different cements used on single crowns and implants by three independent investigators. 37 studies were included in this review because they met the inclusion criteria (prospective and an in vitro study design about implantsupported single crowns; English language; all-ceramic or metal-ceramic superstructures on titanium or zirconia implants) and did not relate to the exclusion criteria (fixed dental prostheses, articles describing other studies; reviews and clinical studies; screw-retained single crowns; neglecting the focus on the retention force after cementation).

Results: In recent years, a high number of various cements for use on implants have been scientifically investigated. A wide range of retention values have been published for each cement type. Furthermore, various influencing factors exist regarding retention of semipermanent cements. Significant correlations have been demonstrated between retention force and cement type, crown pretreatment, taper, abutment surface, internal surface cleaning, cement gap, and the presence of grooves on the abutment (Pearson's bivariate correlation; $\mathrm{P}<0.01$ and $\mathrm{P}<0.05$ ). Artificial ageing, such as a chewing simulation, have been neglected so far in the majority of studies. Thermocycling mostly reduced retentive strength.

Conclusion: This review revealed that there are several influencing factors on the retention of crowns which were temporary cemented on implants abutments. It could be shown that there are significant correlations between retentive strength and different parameters. Due to the inconsistent data situation caused by noncomparable study methodologies, the question of the whether semipermanent cements is superior to the conventional definitive or conventional provisional cements available cannot yet be answered.
\end{abstract}

Keywords: Implantology; Cementation; Semipermanent; Single crowns; Retention

Abbreviations: N: Newton; CAD/CAM: Computer Aided-Design/ Computer Aided-Manufacturing

\section{Background}

Implant-supported crowns can be retained by screws or cement. The advantages of screw fixation primarily affect the peri-implant tissue [1]. A further advantage is the option of accessing the screw channel to loosen or reattach the implant-supported restoration easily [2-5].

Technical complications, including loosening or fracture of the abutment screw, occurred significantly more often with screwretained single crowns than they did with cement-retained single crowns [6]. Although cemented crowns on implants have a lower rate of technical complications compared to screw-retained crowns, they are often only temporarily cemented.

The advantage of cementation is that it is independent of the axial alignment of the implants. Esthetic limitations caused by the visible access are eliminated with cementation [7]. Finally yet importantly, the clinical procedure of cementation is firmly anchored in the everyday practice of dentists. The procedure can be carried out routinely $[3,8]$.

With regard to cementation of the superstructure on implants, a distinction is made between temporary and permanent cements. The bond strength values differ significantly between the bond to 
implant abutments and natural teeth. In particular, zinc phosphate, zinc polycarboxylate and glass ionomer cements showed a wide range between retention values [9-12]. Nevertheless, these cements, including self-adhesive resin cements, are used for permanent cementation of single-tooth crowns on implants [13]. They also serve as comparative values in scientific studies regarding retention values $[4,10,13,14]$. However, provisional cements, such as zinc oxide or eugenol cements, have been recommended for cementation in other studies because of the possibility of retrievability $[4,13,15,16]$ and to allow non-destructive removal of the crown in case of screw loosening. Different studies have described and recommended this treatment option [17-19]. A disadvantage is that temporary cements have poor physical properties. These include high solubility and low tensile strength $[4,13,16]$.

Previous studies have recommended that definitive cements should be used for the cementation of single-tooth restorations and provisional cements for the cementation of multi-unit restorations [9,20,21], as larger restorations may be more likely to require retrievability. Definitive resin cements are the cement of choice for definitive cementation of single-tooth restorations $[9,22,23]$. In general, there is a disagreement as to whether temporary or definitive cements should be used for superstructures on implants [17,18,20,24].

Furthermore the industry offers special cements (ie, semipermanent cements) for the use on implants. They have become popular in recent years because they combine the advantages of removability and increased retentive strength [25].

Because implant abutments are not susceptible to caries, it appears that in addition to the classical properties of cements, such as high biocompatibility, low solubility, easy manipulation, and a sufficiently long working time $[26,27]$, the primary focus is on the required retention. It should be high enough to prevent spontaneous loosening of the crown. Furthermore, semipermanent cements should have the property whereby the restoration can be detached from the tooth or abutment without destruction.

Currently, no official classification exists for provisional, semipermanent, and definitive cements regarding retention values.

It is known that there are various factors influencing successful cementation and adequate retention. A cement gap of $20-40 \mu \mathrm{m}$ is considered ideal $[13,28-31]$. This should allow the outflow of excess cement and consequently guarantee adequate seating forces of the restoration [13]. Other influencing factors such as the abutment surface size, the taper, the geometry of the abutment or the pretreatment of the internal surface of the crown have already been investigated in previous studies and identified as factors influencing retention $[18,32$ 34].

To test the hypothesis that different factors have an influence on retention of temporary cementation of crowns on implant abutments and semipermanent cements do not have relevant advantages compared to conventional definitive cements and conventional temporary cements, a thorough search of the literature was conducted to summarize the data gained so far about cementation on implants.

\section{Materials and Methods}

For this review, a thorough search of the literature was done. The primary database used was PubMed. Additionally, the search was supported by a manual search to check references of relevant studies to find more useful publications. Inclusion, exclusion, and eligibility criteria were calculated to develop a specific search strategy (Tables 1-5). The time range of 2005 to 2020 was chosen for selecting the
Table 1: Inclusion criteria.

\begin{tabular}{|l|l|}
\hline \multicolumn{1}{|c|}{ Study Design } & \multicolumn{1}{c|}{ Prospective; in vitro } \\
\hline Language & English \\
\hline Prosthetic type & Implant-supported single crowns \\
\hline Material (superstructure) & All-ceramic, metal-ceramic \\
\hline Material (implant + abutment) & Titanium, zirconia \\
\hline Year of publication & $2005-2020$ \\
\hline
\end{tabular}

Table 2: Eligibility criteria.

\section{Eligibility criteria}

Any kind of root-form implant with a single crown as the superstructure cemented with different types of cements (definitive, semipermanent, and temporary) to compare retention values after pull-off tests. There were no restrictions regarding the type of implant.

Table 3: Exclusion criteria.

\begin{tabular}{|l|}
\hline \multicolumn{1}{|c|}{ Exclusion criteria } \\
\hline Fixed dental prostheses \\
\hline Articles describing other studies \\
\hline Reviews and clinical studies \\
\hline Screw-retained single crowns \\
\hline Focus not on retention force after cementation \\
\hline
\end{tabular}

Table 4: Overview of the average retention forces for different kinds of cementation.

\begin{tabular}{|c|c|c|c|}
\hline Cementation & $\begin{array}{l}\text { Retention (N) } \\
\text { (after water } \\
\text { storage) }\end{array}$ & References & Duration \\
\hline \multirow{4}{*}{ Temporary } & \multirow{4}{*}{$7-100$} & Botega 2004 [35] & \multirow{3}{*}{ Weeks } \\
\hline & & Lehmann 1976 [36] & \\
\hline & & Mehl 2010 [3] & \\
\hline & & Breeding 1992 [17] & \multirow{5}{*}{$\begin{array}{l}\text { Medium to } \\
\text { long term }\end{array}$} \\
\hline \multirow{4}{*}{ Semipermanent } & \multirow{4}{*}{$50-200$} & Covey 2000 [37] & \\
\hline & & Di Felice 2007 [38] & \\
\hline & & Dudley 2008 [23] & \\
\hline & & Kaar 2006 [39] & \\
\hline \multirow{2}{*}{ Definitive } & $\begin{array}{c}\text { Polycarboxylate } \\
\text { cements: } 307 \pm 96\end{array}$ & \multirow{2}{*}{ Mehl 2013 [3] } & \multirow{2}{*}{ Long term } \\
\hline & $\begin{array}{c}\text { Resin-based } \\
\text { cements: } 480 \pm 48\end{array}$ & & \\
\hline
\end{tabular}

Table 5: Percentage changes of the decementation load related to abutment height for different cement classes.

\begin{tabular}{|l|c|c|}
\hline \multirow{2}{*}{\multicolumn{1}{c}{ Cement }} & \multicolumn{2}{c|}{ Changes of the decementation load (\%) } \\
\cline { 2 - 3 } & $\mathbf{4 . 0} \mathbf{~ m m}$ & $\mathbf{5 . 5} \mathbf{~ m m}$ \\
\hline Zinc oxide, eugenol-free & -45 & -90 \\
\hline Zinc phosphate & -4 & +92 \\
\hline Glass ionomer & +23 & +33 \\
\hline Resin based, self-adhesive & +35 & +16 \\
\hline Methacrylate based & $-80 \%$ & $-68 \%$ \\
\hline
\end{tabular}




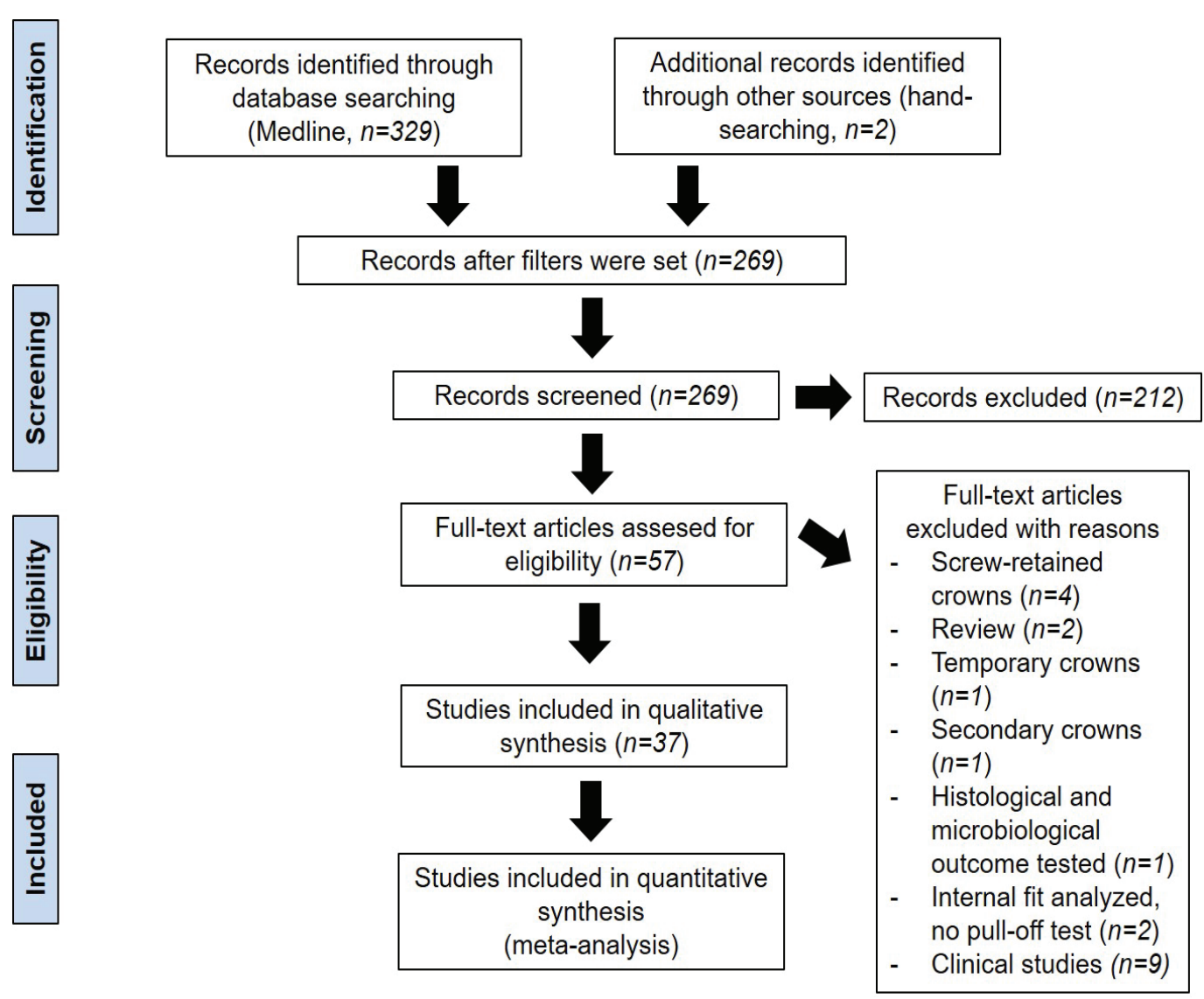

Figure 1: Study selection.

studies (Table 1). The following article types were chosen: journal article, case report, classical article, clinical study, and clinical trial protocol. Regarding the search strategy, a combination of medical subject heading terms and free text words was applied. Various keywords were used to find relevant articles appropriate for answering the hypothesis ("dental AND implant AND crown AND cementation AND retention" and other combinations).

The retention forces found in the studies and the factors influencing them were summarized in table 6 . The correlation between relevant factors and the retention force was determined using Pearson's correlation test (IBM SPSS Statistics for Windows, version 27.0. Armonk, NY, USA, 2020) (Table 7).

\section{Results}

\section{Study selection}

The results of the literature search were 329 hits for the Medline search for the period between 01/01/2005 and 12/01/2020 (last search date: 12/22/2020). For these initially identified papers, 60 articles were excluded because they did not meet the inclusion criteria (Tables 1,3). Two hundred and sixty-nine were screened regarding the titles and abstracts. A further 212 articles were excluded because of the mentioned inclusion and exclusion criteria (Tables 1,3). From checking references, 2 additional articles were found that met the criteria. As a result, 57 articles were evaluated by full-text analysis. In the end, 37 articles were used as data for the analysis in this review (Figure 1, Table 7).

\section{Comparison of retentive strength for different types of cement}

The literature search revealed the following retention values for temporary, semipermanent and definitive cements: For temporary cements, it is important to know the range in which the retention force may be in order to be able to remove the restoration undamaged. At the same time, the retention must be appropriately high to prevent loosening of the crown in everyday use [15,17]. For temporary cementation retention values between 7-100 Newton $(\mathrm{N})$ are considered appropriate (Table 4) $[3,35,36]$. The minimum value of 7 $\mathrm{N}$ results from the retention values for partial dentures that generate sufficient denture retention in the range of 3.5-7 $\mathrm{N}[35,36]$. The maximum value of $100 \mathrm{~N}$ is based on investigations by Mehl C, et al., [3]. Therefore, the number of strokes needed to loosen a cemented implant crown from an abutment was measured [3]. A static force of about $21 \pm 5.6 \mathrm{~N}$ per blow and 10 attempts on average were needed for a dentist to loosen the crown. The upper limit was set to $100 \mathrm{~N}$, which corresponds to approximately 5 blows [3].

For semipermanent cementation, retention values between 50 and $200 \mathrm{~N}$ were measured (Table 4) [17,23,37-39]. In this area, sufficient retention of the crown on the abutment should be ensured. Alternatively, damage-free removal of the crown should be possible if required. Therefore, resin cements with low solubility have been developed in recent years. However, only limited data are available regarding retention values of these newly developed resin cements 
Table 6: Significant correlations between retention force and various parameters as well as the $P$ value.

\begin{tabular}{|l|c|c|}
\hline \multicolumn{1}{|c|}{ Parameter } & $\begin{array}{c}\text { Retention in } \\
\text { Newton (N) }\end{array}$ & P value \\
\hline Cement & $-0.205^{* *}$ & 0.000 \\
\hline $\begin{array}{l}\text { Pretreatment internal crown surface } \\
\text { (sandblasting) }\end{array}$ & $0.158^{* *}$ & 0.000 \\
\hline Taper & $-0.211^{* *}$ & 0.000 \\
\hline Cleaning internal crown surface (alcohol) & $-0.153^{* *}$ & 0.001 \\
\hline Abutment surface size & $-0.118^{*}$ & 0.034 \\
\hline Cement gap & $-0.232^{*}$ & 0.031 \\
\hline Grooves on abutment & $0.139^{* *}$ & 0.002 \\
\hline
\end{tabular}

$* \mathrm{P}<0.05, * * \mathrm{P}<0.01$

created especially for semipermanent cementation of superstructures on implant abutments $[13,15,40]$.

As representatives of the definitive cements, glass ionomer cements, polycarboxylate cements, and resin-based cements were used and tested in most studies [4]. After 3 days of water storage and a pulloff test, the following retention values were obtained for the cements mentioned for a $50 \mu \mathrm{m}$ cement gap: glass ionomer cements $144 \pm 53$ $\mathrm{N}$; polycarboxylate cements $307 \pm 96 \mathrm{~N}$; and resin-based cements 480 $\pm 48 \mathrm{~N}$ (Table 4) [4]

\section{Parameters influencing retention forces}

Cement film thickness: The included studies that examined the cement film thickness showed that for the glass ionomer cement, retention was reduced by $28 \%$ between the $50 \mu \mathrm{m}$ cement gap and the $80 \mu \mathrm{m}$ cement gap, respectively, and the $110 \mu \mathrm{m}$ cement gap. The same did the polycarboxylate cement $(-69 \%)$. The resin-based cement showed homogeneous values for all 3 cements' gap thicknesses [3].

Furthermore great differences existed between the retentive strength before and after thermocycling for the tested temporary cements [41]. Retention values were significantly lower after thermocycling and it also influenced the cement film thickness significantly [41].

\section{Artificial ageing}

Artificial ageing (thermocycling) showed in the majority of the studies that retention decreased afterwards $[9,14,24,40-56]$. Studies that carried out measurements before and after thermocycling published reduced retentive strengths of about $68 \%$ for noneugenol acrylic/urethane resin-based temporary cement, $88 \%$ for zinc oxide noneugenol cement, and $94 \%$ to $98 \%$ for 3 different dual-polymerizing semipermanent resin cements [43].

Effects of compressive cyclic loading on the retention of implant-supported crowns are only available to a limited extent $[40,50,51,53,57,58]$. Compressive cyclic loading leads to a reduced retention of the superstructure of about $50 \%$ for glass ionomer cement, $53 \%$ for compomer cement, and $59 \%$ for resin urethane-based cements [58].

\section{Sandblasting}

The majority of included studies performed sandblasting as a pretreatment of the internal surface of the crowns. The influence of thermocycling and sandblasting on retention was found to affect both components more or less significantly, depending on the cement type [14]. Zinc oxide cements showed the highest retentive strength. Sandblasting was effective for improving the durability. For the other tested cements, the effect of sandblasting was negligible. The retentive strength of zinc oxide cements decreased significantly after thermocycling, even with sandblasting. Consequently, zinc oxide cements were not recommended for the cementation of single crowns on implants [14].

\section{Different geometry of the abutments}

With regard to 2 different abutment heights $(4.0$ and $5.5 \mathrm{~mm}$ ), it was shown that a higher abutment exhibited higher retention values for all tested cements except zinc phosphate cement after water storage (Table 5).

\section{Bivariate correlation analysis}

Pearson's correlation results revealed significant correlations between retention force and various parameters (Tables 6,7). The correlations were significant at the level of $\mathrm{p}<0.01$ and $\mathrm{p}<0.05,2$-sided, respectively.

\section{Discussion}

Regarding the hypothesis that different factors have an influence on retention of temporary cementation of crowns on implant abutments, this literature review showed, that significant correlations between some factors could be proven. As a consequence, when interpreting the retention, it is important to note that it depends not only on the cement properties but also on factors such as the abutment geometry (angle, length, taper and height) and the surface size of the abutment [4]. A significant correlation between retention force and the taper could be shown. The usual taper of abutments is $6^{\circ}$ [4]. Smaller tapers increase the retention, but make cement flow more difficult and can lead to an increase of the occlusion. Larger conicities lead to increased pull-off forces acting on the cement. Retention is therefore closely related to the preparation and decreases with increasing taper [2].

Furthermore the abutment surface size and the abutment geometry (grooves) showed significant correlations regarding retention force. In general, factors such as the abutment height, the diameter, and the surface area have a positive effect on the retention of crowns on abutments [54,59-64]. Height and surface are closely related [7]. The higher the surface and the height of the abutment are, the higher the retention is $[3,18]$. The effect might lose importance when adhesive resin-based cements were used [59]. Axial wall modifications also showed positive effects on retention [65]. Other surface configurations did not always show higher retention values [24]. Additional grooves also increased retention [44]. However, Carnaggio TV, et al., [59] used 3 abutments of different surface sizes $\left(42,60\right.$, and $\left.82 \mathrm{~mm}^{2}\right)$. The results were heterogeneous because the height of the different abutments was the same. Only the circumference was increased. Therefore, there is no linear relationship and a corresponding increase in the pull-off forces between the smallest and the largest abutment surface. For the 2 selfadhesive resin cements, retention values increased by $24 \%$ and $73 \%$ from the 42 to $82 \mathrm{~mm}^{2}$ abutment surface. However the resin-modified glass ionomer cement showed the opposite development (-42\%). Zinc oxide, noneugenol cements only exhibited increased retention values of about $37 \%$ between the smallest and the largest abutment surface sizes. The acrylic-urethane provisional cement showed the highest retentive strength at the middle-abutment surface size.

The cement gap also showed a significant correlation regarding retention. According to Mehl C, et al., [3], the cement film thickness has an influence on retention of the superstructure even if crowns are designed with the help of Computer aided-design/Computer 
aided-manufacturing technology (CAD/CAM) to obtain identical restorations and thus to obtain a homogeneous cement gap [3]. In addition, each specimen, consisting of a crown and abutment, should only be used once to eliminate possible sources of error [59]. Cement residues could damage the abutment surfaces during cleaning. A second cementation would falsify the results [59].

A precise statement with regard to the hypothesis regarding semipermanent cements cannot be made at this time. It can neither be confirmed nor completely rejected. The data situation is heterogeneous. A clear definition of the term semipermanent cementation does not yet exist. Based on this review, a precise definition cannot be established. The biggest problem here is the durability of the crown and various influencing factors. An unambiguous classification into definitive, semipermanent, and temporary cements is hardly possible. In general, retention values of the individual cements differed greatly in various studies. Therefore, some studies published guidelines for clinicians because no cement served for all demands $[13,66]$. Furthermore, the retention values were very different in the individual material classes and therefore not comparable [13]. In detail, it was found that glass ionomer cements might be suitable for semipermanent cementation $[4,41,45,46,60]$ because retention forces should lie between $50-200 \mathrm{~N}$ for semipermanent cementation [17,23,37-39]. Glass ionomer cement develops its full retention over time. In most studies, pull-off tests were immediately performed 24 hours from when the cementation took place. At this time, full retention of the glass ionomer cements had probably not yet been achieved [59]. The use of temporary cements, particularly eugenol-free zinc oxide phosphate cements, led to reduced retention values, especially after thermocycling $[43,54,59,67]$. Consequently, they are not suitable for semipermanent cementation. If retrievability is required after a short time, they might offer a solution to ease removal of the crown $[4,59,68]$. Self-adhesive resin cements, zinc oxide cements, and polycarboxylate cements showed mostly higher retentive strengths regardless of the crown material compared to temporary cements $[4,24,69,70]$. However, retrievability is not possible without destruction of the superstructure [23,71-73].

The correlation analysis showed that certain parameters could have a relevant influence on the retention force of cements. These include cement type, pretreatment and cleaning of the internal crown surface, taper, abutment surface size, cement gap, and grooves on the abutment. However, the interrelationships span the entire spectrum of cementation options (temporary, semipermanent, and definitive).

Retention of cements is mostly measured with the help of pull-off tests that are performed with a universal testing machine. To increase the clinical relevance of in vitro studies, some studies used clinical removal devices for the pull-off tests $[4,45]$. However, the measured values are not comparable with the pull-off forces required intraorally. The Coronaflex device is a special tool that uses compressed air to trigger an impact pulse. This acts on the cement and destroys its structure. The retentive strength is dissolved. The superstructure can be removed and usually it is possible to reuse it. A smaller amount of space in the patient's mouth and the fact that Coronaflex is not always straightforward to apply also makes clinical removal of the crowns more difficult, so that more force is required [4]. In vitro, a simplified removal with less force is possible because the device can be freely positioned and rotated. Schierano G, et al., [74] reported that Coronaflex is more repeatable with higher peak amplitudes of forces, which can be considered as positive.

Some studies have performed thermocycling and evaluated the retention forces of the cements tested $[9,14,24,40-56]$. Thermocycling has been introduced to imitate artificial ageing. Temperature changes as they occur naturally intraorally can be mimicked easily in vitro. The reduction of retention by thermocycling is caused by the regular temperature fluctuations. The thermal stress affects the bonding strength of the cements. Structural changes of the bonds lead to a breakdown of the chemical bond and thus to a failure of the retention between crown and abutment [75]. However, some authors confirmed that thermocycling did not affect retention capacity [53]. Besides, thermocycling is not sufficient for an accurate assessment of the clinical suitability of cements. Long-term mechanical loading (chewing simulation) was only performed to a limited extent [58]. Generally, compressive cyclic loading leads to a reduced retentive strength of cements. Therefore, crowns are easier to remove. Retrievability of the superstructure is achievable, regardless of the cement class $[9,54,58,71]$.

Retentive strength depends on many different factors: the cement type, the cement gap, the cementing technique, the film thickness, the abutment geometry, the surface treatment, and the crown material [3,14,32,42,44,47,49,51,52,55,57,59,61-65,76-91]. In addition, the saliva contamination affects retentive values [48]. Furthermore, many various cements were investigated in different studies with regard to their retention values. Due to noncomparable study protocols and different methodologies, the results cannot reliably be compared.

\section{Conclusion}

The present literature review showed that retention of cemented single crowns on implants depends on a lot of different factors. Significant correlations between retentive strength and different parameters (cement type, cleaning and pretreatment of the internal crown surface, taper, abutment surface size, cement gap, grooves on the abutment) could be proven.

Semipermanent cements that have recently appeared on the market have only shown very limited data so far. From today's point of view, it is not yet possible to say whether they have an advantage compared to conventional definitive or provisional cements. Further studies are required to determine the limitations and possibilities of semipermanent cements.

\section{Declarations}

Ethics approval and consent to participate: Not applicable.

Consent for publication: Not applicable.

Availability of data and material: All data generated can be found online (see Materials and Methods for the search strategy) at PubMed.

Competing interests: Not applicable.

Funding: Not applicable.

Authors' contributions: Jeremias Hey initiated this review. He supervised the entire preparation of this study, gave groundbreaking ideas and supported the literature research. Martin Rosentritt prepared the statistical analysis concerning the factors influencing the retention force (Table 6) and supported the literature search. Florian Beuer performed the final proofreading of the manuscript and supported the creation of this review with helpful tips regarding structuring and outlining. Elisabeth Prause did the literature research and composed the review.

Acknowledgments: Not applicable. 
Table 7: Overview of the included studies with the following information: the cement class used, the material combination between the abutment and the crown, the retention values in Newtons $(\mathrm{N})$, a pretreatment of the crown (alcohol or sandblasting), the particle size of sandblasting in micrometers $(\mu \mathrm{m})$, a conducted thermocycling or chewing simulation, the taper in degrees $\left({ }^{\circ}\right)$, the abutment height in millimeters (mm), the size of the abutment surface in $\left(\mathrm{mm}^{2}\right)$, the size of the cement gap in $\mathrm{mm}$ and the geometry of the abutment in terms of grooves.

\begin{tabular}{|c|c|c|c|c|c|c|c|c|c|c|c|c|}
\hline Author & Cement & $\begin{array}{c}\text { Material } \\
\text { (abutment/ } \\
\text { crown) }\end{array}$ & $\begin{array}{l}\text { Retention } \\
\text { (N) }\end{array}$ & $\begin{array}{c}\text { Pretreatment } \\
\text { crown }\end{array}$ & $\begin{array}{c}\text { Particlesize } \\
\text { sand- } \\
\text { blasting } \\
(\mu \mathrm{m})\end{array}$ & $\begin{array}{l}\text { Thermo- } \\
\text { cycling }\end{array}$ & $\operatorname{Taper}\left({ }^{\circ}\right)$ & $\begin{array}{c}\text { Abutment } \\
\text { height } \\
(\mathrm{mm})\end{array}$ & $\begin{array}{l}\text { Chewing } \\
\text { simulation }\end{array}$ & $\begin{array}{c}\text { Abutment } \\
\text { surface size } \\
\left(\mathrm{mm}^{2}\right)\end{array}$ & $\begin{array}{l}\text { Cement } \\
\text { gap } \\
(\mathrm{mm})\end{array}$ & $\begin{array}{c}\text { Groove } \\
\text { (abutment) }\end{array}$ \\
\hline & zinc phosphate & $\begin{array}{l}\text { titanium- } \\
\text { metal alloy }\end{array}$ & 215.73 & & & & & 5.5 & yes & 33.07 & & \\
\hline & zinc phosphate & & 161.79 & & & & & 5.5 & yes & 33.07 & & \\
\hline & zinc phosphate & & 311.34 & yes & 50 & & & 5.5 & yes & 33.07 & & \\
\hline & zinc phosphate & & 253.48 & yes & 50 & & & 5.5 & yes & 33.07 & & \\
\hline & zinc phosphate & & 383.41 & yes & & & & 5.5 & yes & 33.07 & & \\
\hline & zinc phosphate & & 301.53 & yes & & & & 5.5 & yes & 33.07 & & \\
\hline & zinc phosphate & & 547.17 & yes & 50 & & & 5.5 & yes & 33.07 & & \\
\hline & zinc phosphate & & 531.98 & yes & 50 & & & 5.5 & yes & 33.07 & & \\
\hline \multirow{16}{*}{$\begin{array}{c}\text { Al Hamad } \\
\mathrm{KQ}, \text { et al., } \\
{[62]}\end{array}$} & glass ionomer & $\begin{array}{l}\text { titanium- } \\
\text { metal alloy }\end{array}$ & 183.13 & & & yes & 8 & 4 & & & & \\
\hline & glass ionomer & & 305.14 & yes & 50 & yes & 8 & 4 & & & & \\
\hline & glass ionomer & & 239.95 & & & yes & 8 & 6 & & & & \\
\hline & glass ionomer & & 523.71 & yes & 50 & yes & 8 & 6 & & & & \\
\hline & zinc phosphate & & 268.59 & & & yes & 8 & 4 & & & & \\
\hline & zinc phosphate & & 418.69 & yes & 50 & yes & 8 & 4 & & & & \\
\hline & zinc phosphate & & 647.66 & & & yes & 8 & 6 & & & & \\
\hline & zinc phosphate & & 700.93 & yes & 50 & yes & 8 & 6 & & & & \\
\hline & zinc oxide eugenol & & 65.53 & & & yes & 8 & 4 & & & & \\
\hline & zinc oxide eugenol & & 139.79 & yes & 50 & yes & 8 & 4 & & & & \\
\hline & zinc oxide eugenol & & 73.48 & & & yes & 8 & 6 & & & & \\
\hline & zinc oxide eugenol & & 207.09 & yes & 50 & yes & 8 & 6 & & & & \\
\hline & $\begin{array}{l}\text { zinc oxide eugenol } \\
+ \text { petroleum jelly }\end{array}$ & & 9.86 & & & yes & 8 & 4 & & & & \\
\hline & $\begin{array}{l}\text { zinc oxide eugenol } \\
+ \text { petroleum jelly }\end{array}$ & & 42.09 & yes & 50 & yes & 8 & 4 & & & & \\
\hline & $\begin{array}{l}\text { zinc oxide eugenol } \\
+ \text { petroleum jelly }\end{array}$ & & 17.36 & & & yes & 8 & 6 & & & & \\
\hline & $\begin{array}{l}\text { zinc oxide eugenol } \\
+ \text { petroleum jelly }\end{array}$ & & 48.27 & yes & 50 & yes & 8 & 6 & & & & \\
\hline \multirow[t]{2}{*}{$\begin{array}{c}\text { Abbo B, et } \\
\text { al., [63] }\end{array}$} & resin based & $\begin{array}{l}\text { titanium- } \\
\text { zirconia }\end{array}$ & 124.89 & & & & & 5.5 & & 33.07 & & \\
\hline & resin based & & 198.09 & & & & & 6.5 & & 36.03 & & \\
\hline \multirow[t]{8}{*}{$\begin{array}{c}\text { Carnaggio } \\
\text { TV, et al } \\
{[59]}\end{array}$} & $\begin{array}{l}\text { zinc oxide } \\
\text { noneugenol }\end{array}$ & $\begin{array}{l}\text { titanium- } \\
\text { zirconia }\end{array}$ & 83 & & & & & & & 42 & 100 & \\
\hline & $\begin{array}{c}\text { zinc oxide } \\
\text { noneugenol }\end{array}$ & & 82 & & & & & & & 60 & 100 & \\
\hline & $\begin{array}{c}\text { zinc oxide } \\
\text { noneugenol }\end{array}$ & & 114 & & & & & & & 82 & 100 & \\
\hline & resin based & & 92 & & & & & & & 42 & 100 & \\
\hline & resin based & & 127 & & & & & & & 60 & 100 & \\
\hline & resin based & & 104 & & & & & & & 82 & 100 & \\
\hline & glass ionomer & & 96 & & & & & & & 42 & 100 & \\
\hline & glass ionomer & & 84 & & & & & & & 60 & 100 & \\
\hline
\end{tabular}




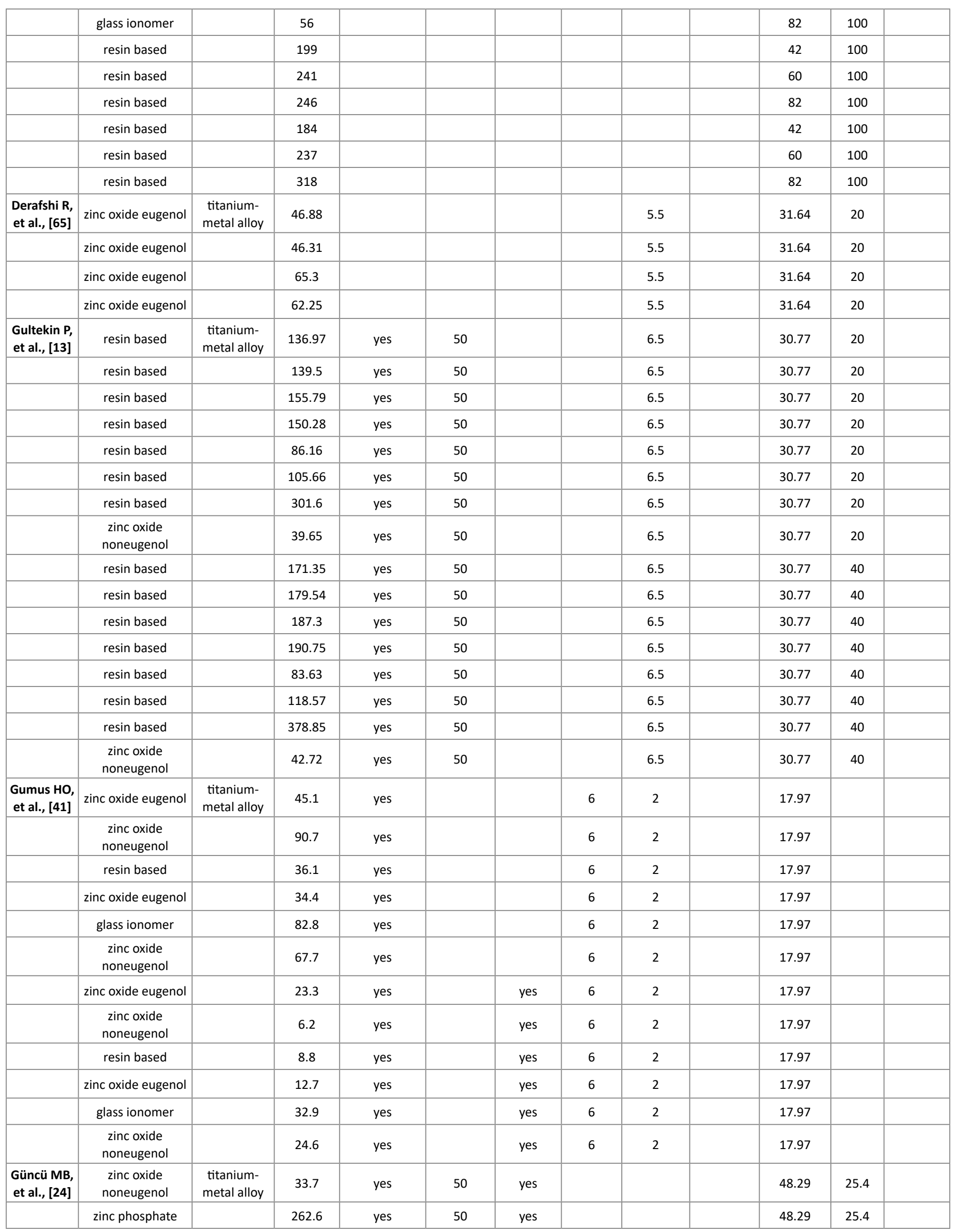




\begin{tabular}{|c|c|c|c|c|c|c|c|c|c|c|}
\hline & glass ionomer & & 75.7 & yes & 50 & yes & & & 48.29 & 25.4 \\
\hline & $\begin{array}{c}\text { zinc oxide } \\
\text { noneugenol }\end{array}$ & & 20.5 & yes & 50 & yes & & & 90 & 25.4 \\
\hline & zinc phosphate & & 258 & yes & 50 & yes & & & 90 & 25.4 \\
\hline & glass ionomer & & 42.1 & yes & 50 & yes & & & 90 & 25.4 \\
\hline \multirow[t]{6}{*}{$\begin{array}{l}\text { Jugdev J, et } \\
\text { al., [85] }\end{array}$} & zinc oxide eugenol & $\begin{array}{l}\text { titanium- } \\
\text { metal alloy }\end{array}$ & 120 & yes & 50 & & & & & \\
\hline & zinc oxide eugenol & & 140 & yes & 50 & & & & & \\
\hline & resin based & & 150 & yes & 50 & & & & & \\
\hline & resin based & & 300 & yes & 50 & & & & & \\
\hline & resin based & & 150 & yes & 50 & & & & & \\
\hline & resin based & & 360 & yes & 50 & & & & & \\
\hline \multirow{4}{*}{$\begin{array}{c}\text { Kilicarslan } \\
\text { MA, et al., } \\
\text { [83] }\end{array}$} & resin based & $\begin{array}{l}\text { titanium- } \\
\text { metal alloy }\end{array}$ & 455.1 & & 50 & & 6 & 5.7 & 37.53 & 20 \\
\hline & resin based & & 565.52 & & 50 & & 6 & 5.7 & 37.53 & 20 \\
\hline & resin based & & 534.78 & & 50 & & 6 & 5.7 & 37.53 & 20 \\
\hline & resin based & & 678.6 & & 50 & & 6 & 5.7 & 37.53 & 20 \\
\hline \multirow[t]{12}{*}{$\begin{array}{l}\text { Kim Y, et } \\
\text { al., [32] }\end{array}$} & calcium-hydroxide & $\begin{array}{l}\text { titanium- } \\
\text { PMMA }\end{array}$ & 48 & & & & & 4 & & \\
\hline & calcium-hydroxide & & 58 & & & & & 4 & & \\
\hline & calcium-hydroxide & & 52 & & & & & 4 & & \\
\hline & $\begin{array}{c}\text { zinc oxide } \\
\text { noneugenol }\end{array}$ & & 39 & & & & & 4 & & \\
\hline & $\begin{array}{c}\text { zinc oxide } \\
\text { noneugenol }\end{array}$ & & 53 & & & & & 4 & & \\
\hline & $\begin{array}{c}\text { zinc oxide } \\
\text { noneugenol }\end{array}$ & & 40 & & & & & 4 & & \\
\hline & zinc oxide eugenol & & 11 & & & & & 4 & & \\
\hline & zinc oxide eugenol & & 20 & & & & & 4 & & \\
\hline & zinc oxide eugenol & & 23 & & & & & 4 & & \\
\hline & zinc oxide eugenol & & 10 & & & & & 4 & & \\
\hline & zinc oxide eugenol & & 12 & & & & & 4 & & \\
\hline & zinc oxide eugenol & & 14 & & & & & 4 & & \\
\hline \multirow[t]{14}{*}{$\begin{array}{l}\text { Kokubo Y, } \\
\text { et al., [14] }\end{array}$} & polycarboxylate & $\begin{array}{l}\text { zirconia- } \\
\text { zirconia }\end{array}$ & 300 & yes & & & 8 & 7.4 & 51.39 & \\
\hline & polycarboxylate & & 120 & yes & & yes & 8 & 7.4 & 51.39 & \\
\hline & polycarboxylate & & 250 & yes & 50 & & 8 & 7.4 & 51.39 & \\
\hline & polycarboxylate & & 275 & yes & 50 & yes & 8 & 7.4 & 51.39 & \\
\hline & polycarboxylate & & 60 & yes & & & 8 & 7.4 & 51.39 & \\
\hline & polycarboxylate & & 40 & yes & & yes & 8 & 7.4 & 51.39 & \\
\hline & polycarboxylate & & 50 & yes & 50 & & 8 & 7.4 & 51.39 & \\
\hline & polycarboxylate & & 20 & yes & 50 & yes & 8 & 7.4 & 51.39 & \\
\hline & zinc oxide eugenol & & 100 & yes & & & 8 & 7.4 & 51.39 & \\
\hline & zinc oxide eugenol & & 60 & yes & & yes & 8 & 7.4 & 51.39 & \\
\hline & zinc oxide eugenol & & 70 & yes & 50 & & 8 & 7.4 & 51.39 & \\
\hline & zinc oxide eugenol & & 70 & yes & 50 & yes & 8 & 7.4 & 51.39 & \\
\hline & $\begin{array}{c}\text { zinc oxide } \\
\text { noneugenol }\end{array}$ & & 120 & yes & & & 8 & 7.4 & 51.39 & \\
\hline & $\begin{array}{c}\text { zinc oxide } \\
\text { noneugenol }\end{array}$ & & 10 & yes & & yes & 8 & 7.4 & 51.39 & \\
\hline
\end{tabular}




\begin{tabular}{|c|c|c|c|c|c|c|c|c|c|c|c|}
\hline & $\begin{array}{c}\text { zinc oxide } \\
\text { noneugenol }\end{array}$ & & 80 & yes & 50 & & 8 & 7.4 & 51.39 & & \\
\hline & $\begin{array}{c}\text { zinc oxide } \\
\text { noneugenol }\end{array}$ & & 5 & yes & 50 & yes & 8 & 7.4 & 51.39 & & \\
\hline & zinc oxide eugenol & & 60 & yes & & & 8 & 7.4 & 51.39 & & \\
\hline & zinc oxide eugenol & & 10 & yes & & yes & 8 & 7.4 & 51.39 & & \\
\hline & zinc oxide eugenol & & 70 & yes & 50 & & 8 & 7.4 & 51.39 & & \\
\hline & zinc oxide eugenol & & 40 & yes & 50 & yes & 8 & 7.4 & 51.39 & & \\
\hline \multirow[t]{5}{*}{$\begin{array}{l}\text { Kurt M, et } \\
\text { al., [42] }\end{array}$} & resin based & $\begin{array}{l}\text { titanium- } \\
\text { metal alloy }\end{array}$ & 249.41 & & & yes & & 4 & & & \\
\hline & resin based & & 315.14 & & & yes & & 4 & & & \\
\hline & resin based & & 506.02 & yes & 50 & yes & & 4 & & & \\
\hline & resin based & & 223.26 & & & yes & & 4 & & & \\
\hline & resin based & & 412.91 & & & yes & & 4 & & & \\
\hline \multirow[t]{10}{*}{\begin{tabular}{|c|} 
Lennartz A, \\
et al., [43]
\end{tabular}} & zinc oxide eugenol & $\begin{array}{l}\text { zirconia- } \\
\text { zirconia }\end{array}$ & 234 & yes & 50 & & 6 & 6 & 34.55 & & \\
\hline & resin based & & 110 & yes & 50 & & 6 & 6 & 34.55 & & \\
\hline & resin based & & 103 & yes & 50 & & 6 & 6 & 34.55 & & \\
\hline & resin based & & 61 & yes & 50 & & 6 & 6 & 34.55 & & \\
\hline & resin based & & 49 & yes & 50 & & 6 & 6 & 34.55 & & \\
\hline & zinc oxide eugenol & & 20 & yes & 50 & yes & 6 & 6 & 34.55 & & \\
\hline & resin based & & 10 & yes & 50 & yes & 6 & 6 & 34.55 & & \\
\hline & resin based & & 10 & yes & 50 & yes & 6 & 6 & 34.55 & & \\
\hline & resin based & & 25 & yes & 50 & yes & 6 & 6 & 34.55 & & \\
\hline & resin based & & 10 & yes & 50 & yes & 6 & 6 & 34.55 & & \\
\hline \multirow[t]{8}{*}{$\begin{array}{c}\text { Lewinstein } \\
\text { I, et al., } \\
{[44]}\end{array}$} & $\begin{array}{c}\text { zinc oxide } \\
\text { noneugenol }\end{array}$ & $\begin{array}{l}\text { titanium- } \\
\text { metal alloy }\end{array}$ & 170 & yes & 110 & yes & 6 & 6 & & & \\
\hline & zinc phosphate & & 362 & yes & 110 & yes & 6 & 6 & & & \\
\hline & $\begin{array}{c}\text { zinc oxide } \\
\text { noneugenol }\end{array}$ & & 188 & yes & 110 & yes & 6 & 6 & & & yes \\
\hline & zinc phosphate & & 580 & yes & 110 & yes & 6 & 6 & & & yes \\
\hline & $\begin{array}{c}\text { zinc oxide } \\
\text { noneugenol }\end{array}$ & & 204 & yes & 110 & yes & 6 & 6 & & & yes \\
\hline & zinc phosphate & & 549 & yes & 110 & yes & 6 & 6 & & & yes \\
\hline & $\begin{array}{c}\text { zinc oxide } \\
\text { noneugenol }\end{array}$ & & 242 & yes & 110 & yes & 6 & 6 & & & yes \\
\hline & zinc phosphate & & 587 & yes & 110 & yes & 6 & 6 & & & yes \\
\hline \multirow[t]{4}{*}{$\begin{array}{c}\text { Mehl C, et } \\
\text { al., [45] }\end{array}$} & glass ionomer & $\begin{array}{l}\text { titanium- } \\
\text { metal alloy }\end{array}$ & 292 & yes & 50 & & 5 & 6 & 34.55 & & yes \\
\hline & glass ionomer & & 264 & yes & 50 & yes & 5 & 6 & 34.55 & & yes \\
\hline & polycarboxylate & & 556 & yes & 50 & & 5 & 6 & 34.55 & & yes \\
\hline & polycarboxylate & & 471 & yes & 50 & yes & 5 & 6 & 34.55 & & yes \\
\hline \multirow[t]{7}{*}{$\begin{array}{c}\text { Mehl C, et } \\
\text { al., [3] }\end{array}$} & glass ionomer & $\begin{array}{l}\text { titanium- } \\
\text { metal alloy }\end{array}$ & 605 & yes & 50 & & 6 & 4 & 28.78 & 20 & \\
\hline & glass ionomer & & 144 & yes & 50 & & 6 & 4 & 28.78 & 50 & \\
\hline & glass ionomer & & 104 & yes & 50 & & 6 & 4 & 28.78 & 80 & \\
\hline & glass ionomer & & 105 & yes & 50 & & 6 & 4 & 28.78 & 110 & \\
\hline & polycarboxylate & & 1041 & yes & 50 & & 6 & 4 & 28.78 & 20 & \\
\hline & polycarboxylate & & 307 & yes & 50 & & 6 & 4 & 28.78 & 50 & \\
\hline & polycarboxylate & & 94 & yes & 50 & & 6 & 4 & 28.78 & 80 & \\
\hline
\end{tabular}




\begin{tabular}{|c|c|c|c|c|c|c|c|c|c|c|c|}
\hline & polycarboxylate & & 96 & yes & 50 & & 6 & 4 & & 28.78 & 110 \\
\hline & resin based & & 1237 & yes & 50 & & 6 & 4 & & 28.78 & 20 \\
\hline & resin based & & 480 & yes & 50 & & 6 & 4 & & 28.78 & 50 \\
\hline & resin based & & 448 & yes & 50 & & 6 & 4 & & 28.78 & 80 \\
\hline & resin based & & 362 & yes & 50 & & 6 & 4 & & 28.78 & 110 \\
\hline \multirow[t]{16}{*}{$\begin{array}{l}\text { Mehl C, et } \\
\text { al., [46] }\end{array}$} & glass ionomer & $\begin{array}{l}\text { titanium- } \\
\text { metal alloy }\end{array}$ & 244 & yes & 50 & & 6 & 4 & & 28.78 & \\
\hline & resin based & & 307 & yes & 50 & & 6 & 4 & & 28.78 & \\
\hline & resin based & & 154 & yes & 50 & & 6 & 4 & & 28.78 & \\
\hline & resin based & & 107 & yes & 50 & & 6 & 4 & & 28.78 & \\
\hline & glass ionomer & & 264 & yes & 50 & yes & 6 & 4 & & 28.78 & \\
\hline & resin based & & 311 & yes & 50 & yes & 6 & 4 & & 28.78 & \\
\hline & resin based & & 93 & yes & 50 & yes & 6 & 4 & & 28.78 & \\
\hline & resin based & & 81 & yes & 50 & yes & 6 & 4 & & 28.78 & \\
\hline & glass ionomer & & 225 & yes & 50 & & 6 & 4 & yes & 28.78 & \\
\hline & resin based & & 275 & yes & 50 & & 6 & 4 & yes & 28.78 & \\
\hline & resin based & & 123 & yes & 50 & & 6 & 4 & yes & 28.78 & \\
\hline & resin based & & 81 & yes & 50 & & 6 & 4 & yes & 28.78 & \\
\hline & glass ionomer & & 235 & yes & 50 & yes & 6 & 4 & yes & 28.78 & \\
\hline & resin based & & 303 & yes & 50 & yes & 6 & 4 & yes & 28.78 & \\
\hline & resin based & & 102 & yes & 50 & yes & 6 & 4 & yes & 28.78 & \\
\hline & resin based & & 86 & yes & 50 & yes & 6 & 4 & yes & 28.78 & \\
\hline \multirow{12}{*}{$\begin{array}{c}\text { Nagasawa } \\
\text { Y, et al., } \\
{[67]}\end{array}$} & polycarboxylate & titanium-gold & 72 & yes & 50 & & 10 & 5 & & 37.2 & 50 \\
\hline & polycarboxylate & & 76 & yes & 50 & & 10 & 5 & & 37.2 & 50 \\
\hline & polycarboxylate & & 110 & yes & 50 & & 10 & 5 & & 37.2 & 50 \\
\hline & polycarboxylate & & 72 & yes & 50 & & 10 & 5 & & 37.2 & 50 \\
\hline & zinc oxide eugenol & & 93 & yes & 50 & & 10 & 5 & & 37.2 & 50 \\
\hline & zinc oxide eugenol & & 81 & yes & 50 & & 10 & 5 & & 37.2 & 50 \\
\hline & $\begin{array}{c}\text { zinc oxide } \\
\text { noneugenol }\end{array}$ & & 82 & yes & 50 & & 10 & 5 & & 37.2 & 50 \\
\hline & $\begin{array}{c}\text { zinc oxide } \\
\text { noneugenol }\end{array}$ & & 70 & yes & 50 & & 10 & 5 & & 37.2 & 50 \\
\hline & zinc oxide eugenol & & 48 & yes & 50 & & 10 & 5 & & 37.2 & 50 \\
\hline & zinc oxide eugenol & & 25 & yes & 50 & & 10 & 5 & & 37.2 & 50 \\
\hline & zinc oxide eugenol & & 26 & yes & 50 & & 10 & 5 & & 37.2 & 50 \\
\hline & zinc oxide eugenol & & 20 & yes & 50 & & 10 & 5 & & 37.2 & 50 \\
\hline \multirow[t]{9}{*}{$\begin{array}{c}\text { Naumova } \\
\text { EA, et al. } \\
{[47]}\end{array}$} & $\begin{array}{c}\text { zinc oxide } \\
\text { noneugenol }\end{array}$ & $\begin{array}{l}\text { titanium- } \\
\text { metal alloy }\end{array}$ & 191.7 & yes & 50 & & 6 & 5.8 & & 33.95 & \\
\hline & glass ionomer & & 902.3 & yes & 50 & & 6 & 5.8 & & 33.95 & \\
\hline & glass ionomer & & 863.6 & yes & 50 & & 6 & 5.8 & & 33.95 & \\
\hline & zinc phosphate & & 615.8 & yes & 50 & & 6 & 5.8 & & 33.95 & \\
\hline & glass ionomer & & 740.1 & yes & 50 & & 6 & 5.8 & & 33.95 & \\
\hline & glass ionomer & & 588.5 & yes & 50 & & 6 & 5.8 & & 33.95 & \\
\hline & resin based & & 334.5 & yes & 50 & & 6 & 5.8 & & 33.95 & \\
\hline & glass ionomer & & 642.2 & yes & 50 & & 6 & 5.8 & & 33.95 & \\
\hline & $\begin{array}{c}\text { zinc oxide } \\
\text { noneugenol }\end{array}$ & & 49.09 & yes & 50 & & 6 & 5.8 & & 33.95 & \\
\hline
\end{tabular}




\begin{tabular}{|c|c|c|c|c|c|c|c|c|c|c|c|c|}
\hline & glass ionomer & & 213.6 & yes & 50 & & 6 & 5.8 & & 33.95 & & \\
\hline & glass ionomer & & 251.4 & yes & 50 & & 6 & 5.8 & & 33.95 & & \\
\hline & zinc phosphate & & 258.1 & yes & 50 & & 6 & 5.8 & & 33.95 & & \\
\hline & glass ionomer & & 242.4 & yes & 50 & & 6 & 5.8 & & 33.95 & & \\
\hline & glass ionomer & & 249.2 & yes & 50 & & 6 & 5.8 & & 33.95 & & \\
\hline & resin based & & 205 & yes & 50 & & 6 & 5.8 & & 33.95 & & \\
\hline & glass ionomer & & 229.1 & yes & 50 & & 6 & 5.8 & & 33.95 & & \\
\hline & $\begin{array}{c}\text { zinc oxide } \\
\text { noneugenol }\end{array}$ & & 30.98 & yes & 50 & & 6 & 5.8 & & 33.95 & & \\
\hline & glass ionomer & & 179.3 & yes & 50 & & 6 & 5.8 & & 33.95 & & \\
\hline & glass ionomer & & 165.3 & yes & 50 & & 6 & 5.8 & & 33.95 & & \\
\hline & zinc phosphate & & 185.3 & yes & 50 & & 6 & 5.8 & & 33.95 & & \\
\hline & glass ionomer & & 178.8 & yes & 50 & & 6 & 5.8 & & 33.95 & & \\
\hline & glass ionomer & & 188.6 & yes & 50 & & 6 & 5.8 & & 33.95 & & \\
\hline & resin based & & 158.9 & yes & 50 & & 6 & 5.8 & & 33.95 & & \\
\hline & glass ionomer & & 150.6 & yes & 50 & & 6 & 5.8 & & 33.95 & & \\
\hline \multirow{9}{*}{$\begin{array}{c}\text { Nejatidanse } \\
\text { F, et al., } \\
\text { [49] }\end{array}$} & resin based & $\begin{array}{l}\text { titanium- } \\
\text { zirconia }\end{array}$ & 203.49 & yes & 110 & yes & 8 & 5.5 & & & & \\
\hline & resin based & & 190.61 & yes & 110 & yes & 8 & 5.5 & & & & \\
\hline & resin based & & 172.16 & yes & 110 & yes & 8 & 5.5 & & & & \\
\hline & zinc phosphate & & 72.01 & yes & 110 & yes & 8 & 5.5 & & & & \\
\hline & polycarboxylate & & 44.18 & yes & 110 & yes & 8 & 5.5 & & & & \\
\hline & glass ionomer & & 3.12 & yes & 110 & yes & 8 & 5.5 & & & & \\
\hline & $\begin{array}{c}\text { zinc oxide } \\
\text { noneugenol }\end{array}$ & & 11.27 & yes & 110 & yes & 8 & 5.5 & & & & \\
\hline & zinc oxide eugenol & & 4.52 & yes & 110 & yes & 8 & 5.5 & & & & \\
\hline & resin based & & 4.03 & yes & 110 & yes & 8 & 5.5 & & & & \\
\hline \multirow{7}{*}{$\begin{array}{c}\text { Nejatidanse } \\
\text { F, et al., } \\
\text { [48] } \\
\end{array}$} & resin based & $\begin{array}{l}\text { titanium- } \\
\text { zirconia }\end{array}$ & 183.9 & yes & & yes & 6 & 5.5 & & & 30 & \\
\hline & resin based & & 123.64 & yes & & yes & 6 & 5.5 & & & 30 & \\
\hline & resin based & & 190.57 & yes & & yes & 6 & 5.5 & & & 30 & \\
\hline & resin based & & 195.43 & yes & 50 & yes & 6 & 5.5 & & & 30 & \\
\hline & resin based & & 204.79 & yes & & yes & 6 & 5.5 & & & 30 & \\
\hline & resin based & & 232.65 & yes & & yes & 6 & 5.5 & & & 30 & \\
\hline & resin based & & 193.11 & yes & & yes & 6 & 5.5 & & & 30 & \\
\hline \multirow[t]{3}{*}{$\begin{array}{c}\text { Ongthiemsak, } \\
\text { et al., [57] }\end{array}$} & zinc oxide eugenol & titanium-gold & 39.94 & yes & 50 & & & & yes & & & \\
\hline & zinc oxide eugenol & & 43.77 & yes & 50 & & & & yes & & & \\
\hline & zinc oxide eugenol & & 47.47 & yes & 50 & & & & yes & & & \\
\hline \multirow[t]{7}{*}{$\begin{array}{c}\text { Pan YH, et } \\
\text { al., [16] }\end{array}$} & $\begin{array}{l}\text { resin based }+ \\
\text { petroleum jelly }\end{array}$ & $\begin{array}{l}\text { titanium- } \\
\text { metal alloy }\end{array}$ & 32 & yes & 50 & yes & & 12 & yes & & & \\
\hline & zinc oxide eugenol & & 36.6 & yes & 50 & yes & & 12 & yes & & & \\
\hline & resin based & & 39.2 & yes & 50 & yes & & 12 & yes & & & \\
\hline & $\begin{array}{c}\text { zinc oxide } \\
\text { noneugenol }\end{array}$ & & 40.8 & yes & 50 & yes & & 12 & yes & & & \\
\hline & resin based & & 45.4 & yes & 50 & yes & & 12 & yes & & & \\
\hline & $\begin{array}{c}\text { zinc phosphate + } \\
\text { petroleum jelly }\end{array}$ & & 147 & yes & 50 & yes & & 12 & yes & & & \\
\hline & zinc phosphate & & 249.2 & yes & 50 & yes & & 12 & yes & & & \\
\hline
\end{tabular}




\begin{tabular}{|c|c|c|c|c|c|c|c|c|c|c|c|}
\hline $\begin{array}{l}\text { Pitta J, et } \\
\text { al., [52] }\end{array}$ & resin based & $\begin{array}{l}\text { titanium- } \\
\text { PMMA }\end{array}$ & 64.1 & yes & & yes & & & & & \\
\hline & resin based & & 64.9 & yes & 50 & yes & & & & & \\
\hline & resin based & & 276.7 & yes & 30 & yes & & & & & \\
\hline & resin based & & 39.1 & yes & 30 & yes & & & & & \\
\hline & resin based & & 1146.5 & yes & & yes & & & & & \\
\hline \multirow[t]{4}{*}{$\begin{array}{l}\text { Pitta J, et } \\
\text { al., [53] }\end{array}$} & resin based & $\begin{array}{l}\text { titanium- } \\
\text { PMMA }\end{array}$ & 206.3 & & & yes & & yes & & & \\
\hline & resin based & & 346.9 & & & yes & & yes & & & \\
\hline & resin based & & 420 & & & yes & & yes & & & \\
\hline & resin based & & 376.1 & & & yes & & yes & & & \\
\hline \multirow[t]{6}{*}{$\begin{array}{l}\text { Reddy SV, } \\
\text { et al., [68] }\end{array}$} & zinc oxide eugenol & $\begin{array}{l}\text { titanium- } \\
\text { metal alloy }\end{array}$ & 258.28 & yes & 50 & & & & & & \\
\hline & zinc oxide eugenol & & 260.68 & yes & 50 & & & & & & \\
\hline & zinc oxide eugenol & & 138.41 & yes & 50 & & & & & & \\
\hline & zinc oxide eugenol & & 138.28 & yes & 50 & & & & & & \\
\hline & resin based & & 184.86 & yes & 50 & & & & & & \\
\hline & resin based & & 152.13 & yes & 50 & & & & & & \\
\hline \multirow[t]{4}{*}{$\begin{array}{l}\text { Rödiger M, } \\
\text { et al., [25] }\end{array}$} & resin based & $\begin{array}{c}\text { titanium- } \\
\text { zirconia }\end{array}$ & 101.1 & yes & 110 & yes & 4.31 & & & & \\
\hline & resin based & & 311.7 & yes & 110 & yes & 6.79 & & & & \\
\hline & resin based & & 447.9 & yes & 110 & yes & 4.31 & & & & \\
\hline & resin based & & 478.7 & yes & 110 & yes & 6.79 & & & & \\
\hline \multirow[t]{20}{*}{$\begin{array}{l}\text { Rohr N, et } \\
\text { al., [72] }\end{array}$} & glass ionomer & $\begin{array}{l}\text { zirconia- } \\
\text { zirconia }\end{array}$ & 196 & yes & & & & & & & \\
\hline & resin based & & 43 & yes & & & & & & & \\
\hline & zinc oxide eugenol & & 127 & yes & & & & & & & \\
\hline & resin based & & 261 & yes & & & & & & & \\
\hline & resin based & & 253 & yes & & & & & & & \\
\hline & resin based & & 270 & yes & & & & & & & \\
\hline & resin based & & 226 & yes & & & & & & & \\
\hline & resin based & & 222 & yes & & & & & & & \\
\hline & resin based & & 238 & yes & & & & & & & \\
\hline & resin based & & 245 & yes & & & & & & & \\
\hline & resin based & & 318 & yes & & & & & & & \\
\hline & resin based & & 254 & yes & & & & & & & \\
\hline & resin based & & 605 & yes & & & & & & & \\
\hline & resin based & & 470 & yes & & & & & & & \\
\hline & resin based & & 257 & yes & & & & & & & \\
\hline & resin based & & 243 & yes & & & & & & & \\
\hline & resin based & & 269 & yes & & & & & & & \\
\hline & resin based & & 224 & yes & & & & & & & \\
\hline & resin based & & 363 & yes & & & & & & & \\
\hline & resin based & & 288 & yes & & & & & & & \\
\hline \multirow[t]{4}{*}{$\begin{array}{l}\text { Rues S, et } \\
\text { al., [54] }\end{array}$} & $\begin{array}{c}\text { zinc oxide } \\
\text { noneugenol }\end{array}$ & $\begin{array}{l}\text { zirconia- } \\
\text { zirconia }\end{array}$ & 31 & yes & 50 & & 4 & & & & \\
\hline & methacrylate based & & 40 & yes & 50 & & 4 & & & & \\
\hline & resin based & & 436 & yes & 50 & & 4 & & & & \\
\hline & zinc phosphate & & 682 & yes & 50 & & 4 & & & & \\
\hline
\end{tabular}




\begin{tabular}{|c|c|c|c|c|c|c|c|c|c|c|c|}
\hline & glass ionomer & & 425 & yes & 50 & & & 4 & & & \\
\hline & $\begin{array}{c}\text { zinc oxide } \\
\text { noneugenol }\end{array}$ & & 17 & yes & 50 & yes & & 4 & & & \\
\hline & methacrylate based & & 8 & yes & 50 & yes & & 4 & & & \\
\hline & resin based & & 590 & yes & 50 & yes & & 4 & & & \\
\hline & zinc phosphate & & 656 & yes & 50 & yes & & 4 & & & \\
\hline & glass ionomer & & 522 & yes & 50 & yes & & 4 & & & \\
\hline & $\begin{array}{c}\text { zinc oxide } \\
\text { noneugenol }\end{array}$ & & 107 & yes & 50 & & & 5.5 & & & \\
\hline & methacrylate based & & 41 & yes & 50 & & & 5.5 & & & \\
\hline & resin based & & 596 & yes & 50 & & & 5.5 & & & \\
\hline & zinc phosphate & & 477 & yes & 50 & & & 5.5 & & & \\
\hline & glass ionomer & & 570 & yes & 50 & & & 5.5 & & & \\
\hline & $\begin{array}{c}\text { zinc oxide } \\
\text { noneugenol }\end{array}$ & & 11 & yes & 50 & yes & & 5.5 & & & \\
\hline & methacrylate based & & 13 & yes & 50 & yes & & 5.5 & & & \\
\hline & resin based & & 689 & yes & 50 & yes & & 5.5 & & & \\
\hline & zinc phosphate & & 915 & yes & 50 & yes & & 5.5 & & & \\
\hline & glass ionomer & & 757 & yes & 50 & yes & & 5.5 & & & \\
\hline \multirow[t]{6}{*}{$\begin{array}{l}\text { Sadig wM, } \\
\text { et al., [89] }\end{array}$} & zinc phosphate & $\begin{array}{l}\text { titanium- } \\
\text { titanium }\end{array}$ & 380 & yes & 50 & & & 5.5 & & & \\
\hline & zinc phosphate & & 180 & yes & 50 & & & 5.5 & & & \\
\hline & zinc phosphate & & 260 & yes & 50 & & & 5.5 & & & \\
\hline & resin based & & 310 & yes & 50 & & & 5.5 & & & \\
\hline & resin based & & 470 & yes & 50 & & & 5.5 & & & \\
\hline & resin based & & 500 & yes & 50 & & & 5.5 & & & \\
\hline \multirow[t]{8}{*}{$\begin{array}{c}\text { Safari S, et } \\
\text { al., [61] }\end{array}$} & resin based & $\begin{array}{l}\text { titanium- } \\
\text { metal alloy }\end{array}$ & 364.19 & yes & & yes & & 3 & 27.69 & 30 & \\
\hline & glass ionomer & & 154.02 & yes & & yes & & 3 & 27.69 & 30 & \\
\hline & zinc oxide eugenol & & 115.99 & yes & & yes & & 3 & 27.69 & 30 & \\
\hline & resin based & & 352.84 & yes & & yes & & 3 & 27.69 & 30 & \\
\hline & resin based & & 460.44 & yes & & yes & & 3 & 31.9 & 30 & \\
\hline & glass ionomer & & 243.68 & yes & & yes & & 3 & 31.9 & 30 & \\
\hline & zinc oxide eugenol & & 164.7 & yes & & yes & & 3 & 31.9 & 30 & \\
\hline & resin based & & 405.45 & yes & & yes & & 3 & 31.9 & 30 & \\
\hline \multirow[t]{3}{*}{$\begin{array}{l}\text { Sahu N, et } \\
\text { al., [82] }\end{array}$} & resin based & $\begin{array}{l}\text { titanium- } \\
\text { metal alloy }\end{array}$ & 408.3 & yes & 110 & & & 8 & & 25 & \\
\hline & resin based & & 159.9 & yes & 110 & & & 8 & & 25 & \\
\hline & resin based & & 743.8 & yes & 110 & & & 8 & & 25 & \\
\hline \multirow[t]{9}{*}{$\begin{array}{l}\text { Schiessl C, } \\
\text { et al., [55] }\end{array}$} & polycarboxylate & $\begin{array}{l}\text { titanium- } \\
\text { metal alloy }\end{array}$ & 400 & yes & 50 & & 4 & 6 & 33.12 & & \\
\hline & polycarboxylate & & 430 & yes & 50 & & 4 & 6 & 33.12 & & \\
\hline & polycarboxylate & & 200 & yes & 50 & & 4 & 6 & 33.12 & & \\
\hline & zinc phosphate & & 270 & yes & 50 & & 4 & 6 & 33.12 & & \\
\hline & methacrylate based & & 80 & yes & 50 & & 4 & 6 & 33.12 & & \\
\hline & glass ionomer & & 180 & yes & 50 & & 4 & 6 & 33.12 & & \\
\hline & resin based & & 270 & yes & 50 & & 4 & 6 & 33.12 & & \\
\hline & $\begin{array}{c}\text { zinc oxide } \\
\text { noneugenol }\end{array}$ & & 130 & yes & 50 & & 4 & 6 & 33.12 & & \\
\hline & polycarboxylate & & 380 & yes & 50 & & 6 & 6 & 33.12 & & \\
\hline
\end{tabular}




\begin{tabular}{|c|c|c|c|c|c|c|c|c|}
\hline polycarboxylate & 240 & yes & 50 & & 6 & 6 & 33.12 & \\
\hline polycarboxylate & 200 & yes & 50 & & 6 & 6 & 33.12 & \\
\hline zinc phosphate & 200 & yes & 50 & & 6 & 6 & 33.12 & \\
\hline methacrylate based & 110 & yes & 50 & & 6 & 6 & 33.12 & \\
\hline glass ionomer & 120 & yes & 50 & & 6 & 6 & 33.12 & \\
\hline resin based & 230 & yes & 50 & & 6 & 6 & 33.12 & \\
\hline $\begin{array}{c}\text { zinc oxide } \\
\text { noneugenol }\end{array}$ & 100 & yes & 50 & & 6 & 6 & 33.12 & \\
\hline polycarboxylate & 320 & yes & 50 & & 8 & 6 & 33.12 & \\
\hline polycarboxylate & 140 & yes & 50 & & 8 & 6 & 33.12 & \\
\hline polycarboxylate & 140 & yes & 50 & & 8 & 6 & 33.12 & \\
\hline zinc phosphate & 160 & yes & 50 & & 8 & 6 & 33.12 & \\
\hline polycarboxylate & 80 & yes & 50 & & 8 & 6 & 33.12 & \\
\hline glass ionomer & 100 & yes & 50 & & 8 & 6 & 33.12 & \\
\hline resin based & 260 & yes & 50 & & 8 & 6 & 33.12 & \\
\hline $\begin{array}{c}\text { zinc oxide } \\
\text { noneugenol }\end{array}$ & 90 & yes & 50 & & 8 & 6 & 33.12 & \\
\hline polycarboxylate & 660 & yes & 50 & yes & 4 & 6 & 33.12 & \\
\hline polycarboxylate & 380 & yes & 50 & yes & 4 & 6 & 33.12 & \\
\hline polycarboxylate & 400 & yes & 50 & yes & 4 & 6 & 33.12 & \\
\hline zinc phosphate & 370 & yes & 50 & yes & 4 & 6 & 33.12 & \\
\hline methacrylate based & 5 & yes & 50 & yes & 4 & 6 & 33.12 & \\
\hline glass ionomer & 300 & yes & 50 & yes & 4 & 6 & 33.12 & \\
\hline resin based & 300 & yes & 50 & yes & 4 & 6 & 33.12 & \\
\hline $\begin{array}{c}\text { zinc oxide } \\
\text { noneugenol }\end{array}$ & 50 & yes & 50 & yes & 4 & 6 & 33.12 & \\
\hline polycarboxylate & 580 & yes & 50 & yes & 6 & 6 & 33.12 & \\
\hline polycarboxylate & 400 & yes & 50 & yes & 6 & 6 & 33.12 & \\
\hline polycarboxylate & 210 & yes & 50 & yes & 6 & 6 & 33.12 & \\
\hline zinc phosphate & 280 & yes & 50 & yes & 6 & 6 & 33.12 & \\
\hline methacrylate based & 5 & yes & 50 & yes & 6 & 6 & 33.12 & \\
\hline glass ionomer & 250 & yes & 50 & yes & 6 & 6 & 33.12 & \\
\hline resin based & 240 & yes & 50 & yes & 6 & 6 & 33.12 & \\
\hline $\begin{array}{c}\text { zinc oxide } \\
\text { noneugenol }\end{array}$ & 40 & yes & 50 & yes & 6 & 6 & 33.12 & \\
\hline polycarboxylate & 620 & yes & 50 & yes & 8 & 6 & 33.12 & \\
\hline polycarboxylate & 400 & yes & 50 & yes & 8 & 6 & 33.12 & \\
\hline polycarboxylate & 250 & yes & 50 & yes & 8 & 6 & 33.12 & \\
\hline zinc phosphate & 250 & yes & 50 & yes & 8 & 6 & 33.12 & \\
\hline methacrylate based & 5 & yes & 50 & yes & 8 & 6 & 33.12 & \\
\hline glass ionomer & 200 & yes & 50 & yes & 8 & 6 & 33.12 & \\
\hline resin based & 210 & yes & 50 & yes & 8 & 6 & 33.12 & \\
\hline $\begin{array}{c}\text { zinc oxide } \\
\text { noneugenol }\end{array}$ & 50 & yes & 50 & yes & 8 & 6 & 33.12 & \\
\hline zinc phosphate & 300 & yes & 50 & & 4 & 6 & 33.12 & \\
\hline glass ionomer & 110 & yes & 50 & & 4 & 6 & 33.12 & \\
\hline $\begin{array}{c}\text { zinc oxide } \\
\text { noneugenol }\end{array}$ & 100 & yes & 50 & & 4 & 6 & 33.12 & \\
\hline
\end{tabular}




\begin{tabular}{|c|c|c|c|c|c|c|c|}
\hline resin based & 250 & yes & 50 & & 4 & 6 & 33.12 \\
\hline zinc phosphate & 210 & yes & 50 & & 6 & 6 & 33.12 \\
\hline glass ionomer & 100 & yes & 50 & & 6 & 6 & 33.12 \\
\hline $\begin{array}{c}\text { zinc oxide } \\
\text { noneugenol }\end{array}$ & 110 & yes & 50 & & 6 & 6 & 33.12 \\
\hline resin based & 270 & yes & 50 & & 6 & 6 & 33.12 \\
\hline zinc phosphate & 180 & yes & 50 & & 8 & 6 & 33.12 \\
\hline glass ionomer & 90 & yes & 50 & & 8 & 6 & 33.12 \\
\hline $\begin{array}{c}\text { zinc oxide } \\
\text { noneugenol }\end{array}$ & 80 & yes & 50 & & 8 & 6 & 33.12 \\
\hline resin based & 260 & yes & 50 & & 8 & 6 & 33.12 \\
\hline zinc phosphate & 280 & yes & 50 & yes & 4 & 6 & 33.12 \\
\hline glass ionomer & 300 & yes & 50 & yes & 4 & 6 & 33.12 \\
\hline $\begin{array}{c}\text { zinc oxide } \\
\text { noneugenol }\end{array}$ & 70 & yes & 50 & yes & 4 & 6 & 33.12 \\
\hline resin based & 320 & yes & 50 & yes & 4 & 6 & 33.12 \\
\hline zinc phosphate & 230 & yes & 50 & yes & 6 & 6 & 33.12 \\
\hline glass ionomer & 180 & yes & 50 & yes & 6 & 6 & 33.12 \\
\hline $\begin{array}{c}\text { zinc oxide } \\
\text { noneugenol }\end{array}$ & 50 & yes & 50 & yes & 6 & 6 & 33.12 \\
\hline resin based & 290 & yes & 50 & yes & 6 & 6 & 33.12 \\
\hline zinc phosphate & 250 & yes & 50 & yes & 8 & 6 & 33.12 \\
\hline glass ionomer & 190 & yes & 50 & yes & 8 & 6 & 33.12 \\
\hline $\begin{array}{c}\text { zinc oxide } \\
\text { noneugenol }\end{array}$ & 40 & yes & 50 & yes & 8 & 6 & 33.12 \\
\hline resin based & 280 & yes & 50 & yes & 8 & 6 & 33.12 \\
\hline zinc phosphate & 380 & yes & 120 & & 4 & 6 & 33.12 \\
\hline glass ionomer & 210 & yes & 120 & & 4 & 6 & 33.12 \\
\hline $\begin{array}{c}\text { zinc oxide } \\
\text { noneugenol }\end{array}$ & 90 & yes & 120 & & 4 & 6 & 33.12 \\
\hline resin based & 260 & yes & 120 & & 4 & 6 & 33.12 \\
\hline zinc phosphate & 350 & yes & 120 & & 6 & 6 & 33.12 \\
\hline glass ionomer & 190 & yes & 120 & & 6 & 6 & 33.12 \\
\hline $\begin{array}{c}\text { zinc oxide } \\
\text { noneugenol }\end{array}$ & 110 & yes & 120 & & 6 & 6 & 33.12 \\
\hline resin based & 210 & yes & 120 & & 6 & 6 & 33.12 \\
\hline zinc phosphate & 340 & yes & 120 & & 8 & 6 & 33.12 \\
\hline glass ionomer & 160 & yes & 120 & & 8 & 6 & 33.12 \\
\hline $\begin{array}{c}\text { zinc oxide } \\
\text { noneugenol }\end{array}$ & 100 & yes & 120 & & 8 & 6 & 33.12 \\
\hline resin based & 220 & yes & 120 & & 8 & 6 & 33.12 \\
\hline zinc phosphate & 350 & yes & 120 & & 4 & 6 & 33.12 \\
\hline glass ionomer & 220 & yes & 120 & & 4 & 6 & 33.12 \\
\hline $\begin{array}{c}\text { zinc oxide } \\
\text { noneugenol }\end{array}$ & 40 & yes & 120 & & 4 & 6 & 33.12 \\
\hline resin based & 260 & yes & 120 & & 4 & 6 & 33.12 \\
\hline zinc phosphate & 280 & yes & 120 & & 6 & 6 & 33.12 \\
\hline glass ionomer & 220 & yes & 120 & & 6 & 6 & 33.12 \\
\hline $\begin{array}{c}\text { zinc oxide } \\
\text { noneugenol }\end{array}$ & 40 & yes & 120 & & 6 & 6 & 33.12 \\
\hline resin based & 210 & yes & 120 & & 6 & 6 & 33.12 \\
\hline zinc phosphate & 280 & yes & 120 & & 8 & 6 & 33.12 \\
\hline
\end{tabular}




\begin{tabular}{|c|c|c|c|c|c|c|c|}
\hline glass ionomer & 210 & yes & 120 & & 8 & 6 & 33.12 \\
\hline $\begin{array}{c}\text { zinc oxide } \\
\text { noneugenol }\end{array}$ & 20 & yes & 120 & & 8 & 6 & 33.12 \\
\hline resin based & 220 & yes & 120 & & 8 & 6 & 33.12 \\
\hline polycarboxylate & 150 & yes & 50 & & 4 & 6 & 33.12 \\
\hline polycarboxylate & 220 & yes & 50 & & 4 & 6 & 33.12 \\
\hline polycarboxylate & 225 & yes & 50 & & 4 & 6 & 33.12 \\
\hline polycarboxylate & 100 & yes & 50 & & 6 & 6 & 33.12 \\
\hline polycarboxylate & 75 & yes & 50 & & 6 & 6 & 33.12 \\
\hline polycarboxylate & 160 & yes & 50 & & 6 & 6 & 33.12 \\
\hline polycarboxylate & 110 & yes & 50 & & 8 & 6 & 33.12 \\
\hline polycarboxylate & 80 & yes & 50 & & 8 & 6 & 33.12 \\
\hline polycarboxylate & 160 & yes & 50 & & 8 & 6 & 33.12 \\
\hline polycarboxylate & 140 & yes & 50 & yes & 4 & 6 & 33.12 \\
\hline polycarboxylate & 290 & yes & 50 & yes & 4 & 6 & 33.12 \\
\hline polycarboxylate & 330 & yes & 50 & yes & 4 & 6 & 33.12 \\
\hline polycarboxylate & 225 & yes & 50 & yes & 6 & 6 & 33.12 \\
\hline polycarboxylate & 240 & yes & 50 & yes & 6 & 6 & 33.12 \\
\hline polycarboxylate & 225 & yes & 50 & yes & 6 & 6 & 33.12 \\
\hline polycarboxylate & 60 & yes & 50 & yes & 8 & 6 & 33.12 \\
\hline polycarboxylate & 350 & yes & 50 & yes & 8 & 6 & 33.12 \\
\hline polycarboxylate & 225 & yes & 50 & yes & 8 & 6 & 33.12 \\
\hline polycarboxylate & 380 & yes & 50 & & 4 & 6 & 33.12 \\
\hline polycarboxylate & 400 & yes & 50 & & 4 & 6 & 33.12 \\
\hline polycarboxylate & 220 & yes & 50 & & 4 & 6 & 33.12 \\
\hline polycarboxylate & 375 & yes & 50 & & 6 & 6 & 33.12 \\
\hline polycarboxylate & 230 & yes & 50 & & 6 & 6 & 33.12 \\
\hline polycarboxylate & 210 & yes & 50 & & 6 & 6 & 33.12 \\
\hline polycarboxylate & 300 & yes & 50 & & 8 & 6 & 33.12 \\
\hline polycarboxylate & 90 & yes & 50 & & 8 & 6 & 33.12 \\
\hline polycarboxylate & 100 & yes & 50 & & 8 & 6 & 33.12 \\
\hline polycarboxylate & 610 & yes & 50 & yes & 4 & 6 & 33.12 \\
\hline polycarboxylate & 375 & yes & 50 & yes & 4 & 6 & 33.12 \\
\hline polycarboxylate & 390 & yes & 50 & yes & 4 & 6 & 33.12 \\
\hline polycarboxylate & 520 & yes & 50 & yes & 6 & 6 & 33.12 \\
\hline polycarboxylate & 380 & yes & 50 & yes & 6 & 6 & 33.12 \\
\hline polycarboxylate & 220 & yes & 50 & yes & 6 & 6 & 33.12 \\
\hline polycarboxylate & 610 & yes & 50 & yes & 8 & 6 & 33.12 \\
\hline polycarboxylate & 390 & yes & 50 & yes & 8 & 6 & 33.12 \\
\hline polycarboxylate & 220 & yes & 50 & yes & 8 & 6 & 33.12 \\
\hline polycarboxylate & 470 & yes & 50 & & 4 & 6 & 33.12 \\
\hline polycarboxylate & 375 & yes & 50 & & 4 & 6 & 33.12 \\
\hline polycarboxylate & 220 & yes & 50 & & 4 & 6 & 33.12 \\
\hline polycarboxylate & 520 & yes & 50 & & 6 & 6 & 33.12 \\
\hline
\end{tabular}




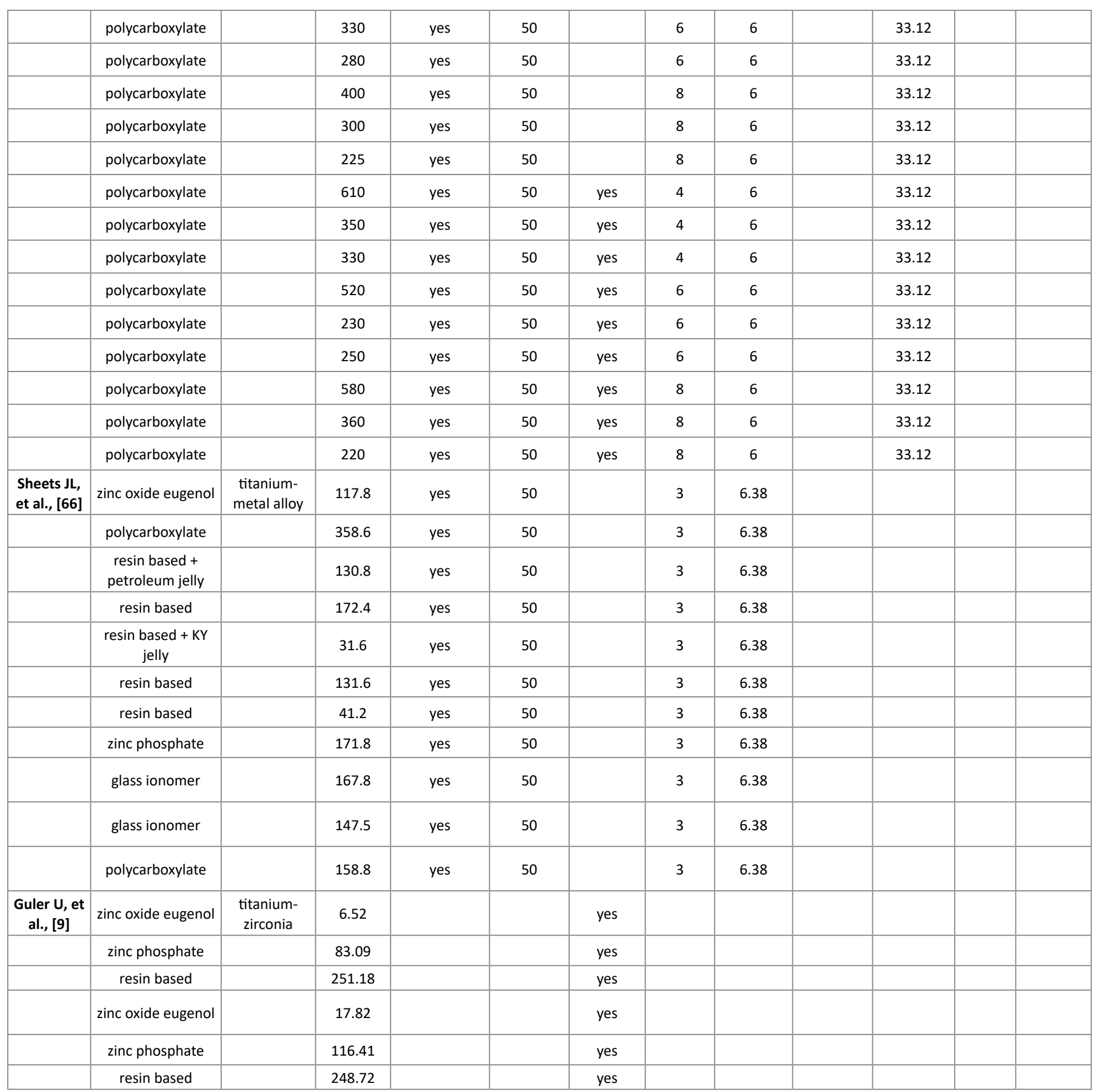

\section{References}

1. Thoma DS, Wolleb K, Bienz SP, Wiedemeier D, Hämmerle CHF, et al. (2018) Early histological, microbiological, radiological, and clinical response to cemented and screw-retained all-ceramic single crowns. Clin Oral Implants Res 29: 996-1006.

2. Duyck J, Naert I (2002) Influence of prosthesis fit and the effect of a luting system on the prosthetic connection preload: an in vitro study. Int J Prosthodont15: 389-396.

3. Mehl C, Harder S, Steiner M, Vollrath O, Kern M (2013) Influence of cement film thickness on the retention of implant-retained crowns. J Prosthodont 22: 618-625.
4. Mehl C, Harder S, Wolfart M, Kern M, Wolfart S (2008) Retrievability of implant-retained crowns following cementation. Clin Oral Implants Res 19: 1304-1311.

5. Torrado E, Ercoli C, Al Mardini M, Graser GN, Tallents RH, et al. (2004) A comparison of the porcelain fracture resistance of screwretained and cement-retained implant-supported metal-ceramic crowns. J Prosthet Dent 91: 532-537.

6. Sailer I, Muhlemann S, Zwahlen M, Hammerle $\mathrm{CH}$, Schneider D (2012) Cemented and screw-retained implant reconstructions: a systematic review of the survival and complication rates. Clin Oral Implants Res 23: S163-S201. 
7. Chee W, Felton DA, Johnson PF, Sullivan DY (1999) Cemented versus screw-retained implant prostheses: which is better? Int J Oral Maxillofac Implants 14: 137-141.

8. Assenza B, Scarano A, Leghissa G, Carusi G, Thams U, et al. (2005) Screw- vs cement-implant-retained restorations: an experimental study in the Beagle. Part 1. Screw and abutment loosening. J Oral Implantol 31: 242-246.

9. Guler U, Budak Y, Queiroz JRC, Ozcan M (2017) Dislodgement Resistance of Zirconia Copings Cemented onto Zirconia and Titanium Abutments. Implant Dent 26: 510-515.

10. Wolfart M, Wolfart S, Kern M (2006) Retention forces and seating discrepancies of implant-retained castings after cementation. Int J Oral Maxillofac Implants 21: 519-525.

11. Montenegro AC, Machado AN, Depes Gouvea CV (2008) Tensile strength of cementing agents on the CeraOne system of dental prosthesis on implants. Implant Dent 17: 451-460.

12. Nejatidanesh F, Savabi O, Ebrahimi M, Savabi G (2012) Retentiveness of implant-supported metal copings using different luting agents. Dent Res J (Isfahan) 9: 13-18.

13. Gultekin P, Gultekin BA, Aydin M, Yalcin S (2013) Cement selection for implant-supported crowns fabricated with different luting space settings. J Prosthodont 22: 112-119.

14. Kokubo Y, Kano T, Tsumita M, Sakurai S, Itayama A, et al. (2010) Retention of zirconia copings on zirconia implant abutments cemented with provisional luting agents. J Oral Rehabil 37: 48-53.

15. Heinemann F, Mundt T, Biffar R (2006) Retrospective evaluation of temporary cemented, tooth and implant supported fixed partial dentures. J Craniomaxillofac Surg 34: S86-S90.

16. Pan YH, Ramp LC, Lin CK, Liu PR (2006) Comparison of 7 luting protocols and their effect on the retention and marginal leakage of a cement-retained dental implant restoration. Int J Oral Maxillofac Implants 21: 587-592.

17. Breeding LC, Dixon DL, Bogacki MT, Tietge JD (1992) Use of luting agents with an implant system: Part I. J Prosthet Dent 68: 737-741.

18. Hebel KS, Gajjar RC (1997) Cement-retained versus screw-retained implant restorations: achieving optimal occlusion and esthetics in implant dentistry. J Prosthet Dent 77: 28-35.

19. Ekfeldt A, Carlsson GE, Borjesson G (1994) Clinical evaluation of single-tooth restorations supported by osseointegrated implants: a retrospective study. Int J Oral Maxillofac Implants 9: 179-183.

20. Akca K, Iplikcioglu H, Cehreli MC (2002) Comparison of uniaxial resistance forces of cements used with implant-supported crowns. Int J Oral Maxillofac Implants17: 536-542.

21. Hill EE (2007) Dental cements for definitive luting: a review and practical clinical considerations. Dent Clin North Am 51: 643-658.

22. Ramp MH, Dixon DL, Ramp LC, Breeding LC, Barber LL (1999) Tensile bond strengths of provisional luting agents used with an implant system. J Prosthet Dent 81: 510-514.

23. Dudley JE, Richards LC, Abbott JR (2008) Retention of cast crown copings cemented to implant abutments. Aust Dent J 53: 332-339.

24. Guncu MB, Cakan U, Canay S (2011) Comparison of 3 luting agents on retention of implant-supported crowns on 2 different abutments. Implant Dent 20: 349-353.

25. Rodiger M, Rinke S, Ehret-Kleinau F, Pohlmeyer F, et al. (2014) Evaluation of removal forces of implant-supported zirconia copings depending on abutment geometry, luting agent and cleaning method during re-cementation. J Adv Prosthodont 6: 233-240.
26. Parisay I, Khazaei Y (2018) Evaluation of retentive strength of four luting cements with stainless steel crowns in primary molars: An in vitro study. Dent Res J (Isfahan) 15: 201-207.

27. Habib B, von Fraunhofer JA, Driscoll CF (2005) Comparison of two luting agents used for the retention of cast dowel and cores. J Prosthodont 14: 164-169.

28. Passon C, Lambert RH, Lambert RL, Newman S (1992) The effect of multiple layers of die-spacer on crown retention. Oper Dent 17: 4249.

29. Campbell SD (1990) Comparison of conventional paint-on die spacers and those used with the all-ceramic restorations. J Prosthet Dent 63: 151-155.

30. Emtiaz S, Goldstein G (1997) Effect of die spacers on precementation space of complete-coverage restorations. Int J Prosthodont 10: 131135.

31. Webb EL, Murray HV, Holland GA, Taylor DF (1983) Effects of preparation relief and flow channels on seating full coverage castings during cementation. J Prosthet Dent 49: 777-780.

32. Kim Y, Yamashita J, Shotwell JL, Chong KH, Wang HL (2006) The comparison of provisional luting agents and abutment surface roughness on the retention of provisional implant-supported crowns. J Prosthet Dent 95: 450-455.

33. Jorgensen KD (1955) The relationship between retention and convergence angle in cemented veneer crowns. Acta Odontol Scand 13: $35-40$.

34. Gilboe DB, Teteruck WR (1974) Fundamentals of extracoronal tooth preparation. Part I. Retention and resistance form. J Prosthet Dent 32: 651-656.

35. Botega DM, Mesquita MF, Henriques GE, Vaz LG (2004) Retention force and fatigue strength of overdenture attachment systems. J Oral Rehabil 31: 884-889.

36. Lehmann KM, Arnim F (1976) Studies on the retention capability of push-button attachments. SSO Schweiz Monatsschr Zahnheilkd 86: 521-530.

37. Covey DA, Kent DK, St Germain HA Jr, Koka S (2000) Effects of abutment size and luting cement type on the uniaxial retention force of implant-supported crowns. J Prosthet Dent 83: 344-348.

38. Di Felice R, Rappelli G, Camaioni E, Cattani M, Meyer JM, et al. (2007) Cementable implant crowns composed of cast superstructure frameworks luted to electroformed primary copings: an in vitro retention study. Clin Oral Implants Res 18: 108-113.

39. Kaar D, Oshida Y, Andres CJ, Barco MT, Platt JA (2006) The effect of fatigue damage on the force required to remove a restoration in a cement-retained implant system. J Prosthodont 15: 289-294.

40. Pan YH, Lin CK (2005) The effect of luting agents on the retention of dental implant-supported crowns. Chang Gung Med J 28: 403-410.

41. Gumus HO, Kurtulus IL, Kuru E (2018) Evaluation and comparison of the film thicknesses of six temporary cements before and after thermal cycling. Niger J Clin Pract 21: 1656-1661.

42. Kurt M, Kulunk T, Ural C, Kulunk S, Danisman S, et al. (2013) The effect of different surface treatments on cement-retained implantsupported restorations. J Oral Implantol 39: 44-51.

43. Lennartz A, Dohmen A, Bishti S, Fischer H, Wolfart S (2018) Retrievability of implant-supported zirconia restorations cemented on zirconia abutments. J Prosthet Dent 120: 740-746. 
44. Lewinstein I, Block L, Lehr Z, Ormianer Z, Matalon S (2011) An in vitro assessment of circumferential grooves on the retention of cementretained implant-supported crowns. J Prosthet Dent 106: 367-372.

45. Mehl C, Harder S, Schwarz D, Steiner M, Vollrath O, et al. (2012) In vitro influence of ultrasonic stress, removal force preload and thermocycling on the retrievability of implant-retained crowns. Clin Oral Implants Res 23: 930-937.

46. Mehl C, Ali S, El Bahra S, Harder S, Vollrath O, et al. (2016) Is There a Correlation Between Tensile Strength and Retrievability of Cemented Implant-Retained Crowns Using Artificial Aging? Int J Prosthodont 29: 83-90.

47. Naumova EA, Roth F, Geis B, Baulig C, Arnold WH, et al. (2018) Influence of Luting Materials on the Retention of Cemented ImplantSupported Crowns: An In vitro Study. Materials (Basel) 11: 1853.

48. Nejatidanesh F, Savabi O, Savabi G, Razavi M (2018) Effect of cleaning methods on retentive values of saliva-contaminated implantsupported zirconia copings. Clin Oral Implants Res 29: 530-536.

49. Nejatidanesh F, Savabi O, Shahtoosi M (2013) Retention of implantsupported zirconium oxide ceramic restorations using different luting agents. Clin Oral Implants Res 24: 20-24.

50. Pan YH, Ramp LC, Lin CK, Liu PR (2007) Retention and leakage of implant-supported restorations luted with provisional cement: a pilot study. J Oral Rehabil 34: 206-212.

51. Pitta J, Bijelic-Donova J, Burkhardt F, Fehmer V, Narhi T, et al. (2020) Temporary Implant-Supported Single Crowns Using Titanium Base Abutments: An In vitro Study on Bonding Stability and Pull-out Forces. Int J Prosthodont 33: 546-552.

52. Pitta J, Burkhardt F, Mekki M, Fehmer V, Mojon P, et al. (2020) Effect of airborne-particle abrasion of a titanium base abutment on the stability of the bonded interface and retention forces of crowns after artificial aging. J Prosthet Dent 126: 214-221.

53. Rohr N, Balmer M, Muller JA, Martin S, Fischer J (2019) Chewing simulation of zirconia implant supported restorations. J Prosthodont Res 63: 361-367.

54. Rues S, Fugina M, Rammelsberg P, Kappel S (2017) Cemented Single Crown Retention on Dental Implants: An In vitro Study. Int Prosthodont 30: 133-135.

55. Schiessl C, Schaefer L, Winter C, Fuerst J, Rosentritt M, et al. (2013) Factors determining the retentiveness of luting agents used with metal- and ceramic-based implant components. Clin Oral Investig 17: 1179-1190.

56. Sellers K, Powers JM, Kiat-Amnuay S (2017) Retentive strength of implant-supported CAD-CAM lithium disilicate crowns on zirconia custom abutments using 6 different cements. J Prosthet Dent 117: 247-252.

57. Ongthiemsak C, Mekayarajjananonth T, Winkler S, Boberick KG (2005)The effect of compressive cyclic loading on retention of a temporary cement used with implants. J Oral Implantol 31: 115-120.

58. Alvarez-Arenal A, Gonzalez-Gonzalez I, Pines-Hueso J, deLlanosLanchares H, del Rio Highsmith J (2016) The Effect of Compressive Cyclic Loading on the Retention of Cast Single Crowns Cemented to Implant Abutments. Int J Prosthodont 29: 80-82.

59. Carnaggio TV, Conrad R, Engelmeier RL, Gerngross P, Paravina R, et al. (2012) Retention of CAD/CAM all-ceramic crowns on prefabricated implant abutments: an in vitro comparative study of luting agents and abutment surface area. J Prosthodont 21: 523-528.
60. Bresciano M, Schierano G, Manzella C, Screti A, Bignardi C, et al. (2005) Retention of luting agents on implant abutments of different height and taper. Clin Oral Implants Res16: 594-598.

61. Safari S, Hosseini Ghavam F, Amini P, Yaghmaei K (2018) Effects of abutment diameter, luting agent type, and re-cementation on the retention of implant-supported CAD/CAM metal copings over short abutments. J Adv Prosthodont 10: 1-7

62. Al Hamad KQ, Al Rashdan BA, Abu-Sitta EH (2011) The effects of height and surface roughness of abutments and the type of cement on bond strength of cement-retained implant restorations. Clin Oral Implants Res 22: 638-644.

63. Abbo B, Razzoog ME, Vivas J, Sierraalta M (2008) Resistance to dislodgement of zirconia copings cemented onto titanium abutments of different heights. J Prosthet Dent 99: 25-29.

64. Rodiger M, Kloss J, Gersdorff N, Burgers R, Rinke S (2018) Remova forces of adhesively and self-adhesively luted implant-supported zirconia copings depend on abutment geometry. J Mech Behav Biomed Mater 87: 119-123.

65. Derafshi R, Ahangari AH, Torabi K, Farzin M (2015) Evaluation of the Effect of Axial Wall Modification and Coping Design on the Retention of Cement-retained Implant-supported Crowns. J Dent Res Dent Clin Dent Prospects9: 35-39.

66. Sheets JL, Wilcox C, Wilwerding T (2008) Cement selection for cement-retained crown technique with dental implants. J Prosthodont 17: 92-96.

67. Nagasawa $Y$, Hibino $Y$, Nakajima H (2014) Retention of crowns cemented on implant abutments with temporary cements. Dent Mater J 33: 835-844.

68. Reddy SV, Reddy MS, Reddy CR, Pithani P, R SK, et al. (2015) The influence of implant abutment surface roughness and the type of cement on retention of implant supported crowns. J Clin Diagn Res 9: ZCO5- ZCO7.

69. Woelber JP, Ratka-Krueger P, Vach K, Frisch E (2016) Decementation Rates and the Peri-Implant Tissue Status of Implant-Supported Fixed Restorations Retained via Zinc Oxide Cement: A Retrospective 1023-Year Study. Clin Implant Dent Relat Res 18: 917-925.

70. Sorrentino R, Galasso L, Tete S, De Simone G, Zarone F (2012) Clinical evaluation of 209 all-ceramic single crowns cemented on natural and implant-supported abutments with different luting agents: a 6-year retrospective study. Clin Implant Dent Relat Res 14: 184-197.

71. Lopes ACO, Machado CM, Bonjardim LR, Bergamo ETP, Ramalho IS et al. (2019) The Effect of CAD/CAM Crown Material and Cement Type on Retention to Implant Abutments. J Prosthodont 28: e552-e556.

72. Rohr N, Brunner S, Martin S, Fischer J (2018) Influence of cement type and ceramic primer on retention of polymer-infiltrated ceramic crowns to a one-piece zirconia implant. J Prosthet Dent 119: 138145.

73. Mehl C, Harder S, Shahriari A, Steiner M, Kern M (2012) Influence of abutment height and thermocycling on retrievability of cemented implant-supported crowns. Int J Oral Maxillofac Implants 27: 11061115.

74. Schierano G, Manzella C, Menicucci G, Parrotta A, Zanetti EM, et al. (2016) In vitro standardization of two different removal devices in cemented implant prosthesis. Clin Oral Implants Res 27: 1026-1030. 
75. Saghiri MA, Asatourian A, Garcia-Godoy F, Gutmann JL, Sheibani $N$ (2013) The impact of thermocycling process on the dislodgement force of different endodontic cements. Biomed Res Int.

76. Enkling N, Ueda T, Gholami H, Bayer S, Katsoulis J, et al. (2014) Precision of fit and retention force of cast non-precious-crowns on standard titanium implant-abutment with different design and height. Clin Oral Implants Res 25: 451-457.

77. Liang $\mathrm{T}$, Hu X, Zhu L, Pan X, Zhou Y, et al. (2016) Comparative in vitro study of cementing techniques for implant-supported restorations. J Prosthet Dent 116: 59-66.

78. Worni A, Gholami H, Marchand L, Katsoulis J, Mericske-Stern R, et al. (2015) Retrievability of implant-supported crowns when using three different cements: a controlled clinical trial. Int J Prosthodont 28: 22-29.

79. Sadighpour L, Geramipanah F, Fazel A, Allahdadi M, Kharazifard MJ (2018) Effect of Selected Luting Agents on the Retention of CAD/ CAM Zirconia Crowns Under Cyclic Environmental Pressure. J Dent (Tehran) 15: 97-105.

80. Cano-Batalla J, Soliva-Garriga J, Campillo-Funollet M, MunozViveros CA, Giner-Tarrida L (2012) Influence of abutment height and surface roughness on in vitro retention of three luting agents. Int J Oral Maxillofac Implants 27: 36-41.

81. Ajay R, Suma K, Ali SA, Kumar Sivakumar JS, Rakshagan V, et al. (2017) Effect of Surface Modifications on the Retention of Cementretained Implant Crowns under Fatigue Loads: An In vitro Study. J Pharm Bioallied Sci 9: S154-S160.

82. Sahu N, Lakshmi N, Azhagarasan NS, Agnihotri Y, Rajan M, et al. (2014) Comparison of the effect of implant abutment surface modifications on retention of implant-supported restoration with a polymer based cement. J Clin Diagn Res 8: 239-242.
83. Kilicarslan MA, Ozkan P (2013) Evaluation of retention of cemented laser-sintered crowns on unmodified straight narrow implant abutments. Int J Oral Maxillofac Implants 28: 381-387.

84. Weyhrauch M, Igiel C, Wentaschek S, Pabst AM, Scheller $H$, et al. (2014) Retentive strength of monolithic all-ceramic crowns on implant abutments. Int J Comput Dent 17: 135-144.

85. Jugdev J, Borzabadi-Farahani A, Lynch E (2014) The effect of air abrasion of metal implant abutments on the tensile bond strength of three luting agents used to cement implant superstructures: an in vitro study. Int J Oral Maxillofac Implants 29: 784-790.

86. T P Bergamo E, Zahoui A, Luri Amorin Ikejiri L, Marun M, Peixoto da Silva K, et al. (2020) Retention of zirconia crowns to Ti-base abutments: effect of luting protocol, abutment treatment and autoclave sterilization. J Prosthodont Res 65: 171-175.

87. Ebert A, Hedderich J, Kern M (2007) Retention of zirconia ceramic copings bonded to titanium abutments. Int J Oral Maxillofac Implants 22: 921-927.

88. Rappelli G, Corso M, Coccia E, Camaioni E, Di Felice R, et al. (2008) In vitro retentive strength of metal superstructures cemented to solid abutments. Minerva Stomatol 57: 95-101.

89. Sadig WM, Al Harbi MW (2007) Effects of surface conditioning on the retentiveness of titanium crowns over short implant abutments. Implant Dent 16: 387-396.

90. Sailer I, Sailer T, Stawarczyk B, Jung RE, Hammerle CH (2009) In vitro study of the influence of the type of connection on the fracture load of zirconia abutments with internal and external implant-abutment connections. Int J Oral Maxillofac Implants 24: 850-858.

91. de Campos TN, Adachi LK, Miashiro K, Yoshida H, Shinkai RS, et al. (2010) Effect of surface topography of implant abutments on retention of cemented single-tooth crowns. Int J Periodontics Restorative Dent 30: 409-413. 